\title{
Complexity of Groundwater Contaminants at DOE Sites
}

\author{
Terry C. Hazen ${ }^{1,2, *}$, Boris Faybishenko ${ }^{1}$, and Preston Jordan $^{1}$ \\ ${ }^{1}$ Lawrence Berkeley National Laboratory, Earth Sciences Division, Berkeley, CA 94720 \\ ${ }^{2}$ Virtual Institute for Microbial Stress and Survival, http://vimss.lbl.gov
}

September 2008

\section{Introduction}

The U.S. Department of Energy (DOE) is responsible for the remediation and long-term stewardship of one of the world's largest groundwater contamination portfolios, with a significant number of plumes containing various contaminants, and considerable total mass and activity (1; 2). As of 1999, the DOE's Office of Environmental Management was responsible for remediation, waste management, or nuclear materials and facility stabilization at 144 sites in 31 states and one U.S. territory, out of which 109 sites were expected to require long-term stewardship (3, p.25). Currently, 19 DOE sites are on the National Priority List (6). The total number of contaminated plumes on DOE lands is estimated to be 10,000 (7). However, a significant number of DOE sites have not yet been fully characterized (6). The most prevalent contaminated media are groundwater and soil, although contaminated sediment, sludge, and surface water also are present. Groundwater, soil, and sediment contamination are present at $72 \%$ of all DOE sites (6, Page 1-14).

A proper characterization of the contaminant inventory at DOE sites is critical for accomplishing one of the primary DOE missions - planning basic research to understand the complex physical, chemical, and biological properties of contaminated sites (the 20-year Strategic Plan of DOE's Office Science Office, February 2004 (8). (Note that the definitions of the terms "site" and "facility" may differ from one publication to another. In this report, the terms "site," "facility" or "installation" are used to identify a contiguous land area within the borders of a property, which may contain more than one plume. The term "plume" is used here to indicate an individual area of contamination, which can be small or large.)

Even though several publications and databases contain information on groundwater contamination and remediation technologies (e.g., 6, 9-17), no statistical analyses of the contaminant inventory at DOE sites has been prepared since the 1992 report by Riley and Zachara (18). The DOE Groundwater Data Base (GWD) (16) presents data as of 2003 for 221 groundwater plumes at 60 DOE sites and facilities (listed in Table S1 in Supporting Information). Note that Riley and Zachara (18) analyzed the data from only 18 sites/facilities including 91 plumes.

In this paper, we present the results of statistical analyses of the data in the GWD (16) as guidance for planning future basic and applied research of groundwater contaminants within the DOE complex. Our analyses include the evaluation of a frequency and ranking of specific

*Corresponding author e-mail: tchazen@llbl.gov, phone: 510-486-6223, fax: 510-486-7152 
contaminants and contaminant groups, contaminant concentrations/activities and total contaminant masses and activities. We also compared the results from analyses of the GWD with those from the 1992 report by Riley and Zachara (18). The difference between our results and those summarized in the 1992 report by Riley and Zachara (18) could be caused by not only additional releases, but also by the use of modern site characterization methods, which more accurately reveal the extent of groundwater contamination.

Contaminated sites within the DOE complex are located in all major geographic regions of the United States, with highly variable geologic, hydrogeologic, soil, and climatic conditions. We assume that the information from the 60 DOE sites included in the GWD (16) are representative for the whole DOE complex. These 60 sites include the major DOE sites and facilities, such Rocky Flats Environmental Technology Site, Colorado; Idaho National Laboratory, Idaho; Savannah River Site, South Carolina; Oak Ridge Reservation, Tennessee; and Hanford Reservation, Washington. These five sites alone account for $71 \%$ of the value of the remediation work (6, pp. 1-9). For assumptions and uncertainties used in this paper see Section S1 in Supporting Information. For the results of testing the integrity of the GWD see Section S2 in Supporting Information.

\section{Frequency of Occurrence of Contaminants}

Contaminant Groups. The GWD contaminants detected in groundwater at $60 \mathrm{DOE}$ sites and facilities can be grouped into the following eight contaminant groups:

- Chlorinated hydrocarbons

- Fuels and fuel components (i.e., petroleum/fuel hydrocarbons)

- Explosives

- Metals

- Radioactive isotopes (excluding tritium)

- Tritium

- Sulfates

- Nitrates

We identified tritium as an individual contaminant group (apart from other radioisotopes, which are combined in a separate group), because tritium is present in groundwater only in a dissolved state. Tritium in groundwater is subject to the processes of radioactive decay, dispersion, or dilution, with no transformation between the dissolved and solid states. Contrary to tritium, other radioactive isotopes are affected by radionuclide transformation between the dissolved and solid states.

Table S1 in Supporting Information lists the types of contaminant groups for each groundwater plume. In their 1992 report, Riley and Zachara (18) also identified the presence of radionuclides, metals, organic solvents, and fuel hydrocarbons. In addition, they identified polychlorinated biphenyls (PCBs) and organic ligands. Five contaminant groups (chlorinated hydrocarbons, fuel and fuel components, explosives, metals, and radioactive isotopes) contain more than one contaminant, and three groups include only a single component (tritium, sulfates, or nitrates). The most frequent contaminant groups (as percentage of the number of plumes surveyed for this contaminant group) are: chlorinated hydrocarbons $(84 \%)$, tritium (51\%), other radioactive isotopes (47\%), nitrates (46\%), metals (43\%), sulfates $(32 \%)$, fuel $(11 \%)$, and explosives (10\%) (Table S2). 
Statistical analysis shows that single contaminants are contained in $23.5 \%$ of all plumes, binary combinations of contaminant groups are found in $29.4 \%$, ternary - in $29 \%$, quaternary in $11.8 \%$, and quinary - in 5\% (Figure S1). The most frequent binary combinations of contaminant groups are those of mixed waste, including chlorinated hydrocarbons and tritium$35 \%$ of all plumes, metals and isotopes - $28 \%$, chlorinated hydrocarbons and isotopes - $24 \%$, isotopes and nitrate-23\% (Figure 2. See also Table S3). Chlorinated hydrocarbons are also found in association with nitrate (30\% of plumes), sulfate $(26 \%)$, and metals $(24 \%)$. A binary combination of radioactive contaminants, including tritium and other radioactive isotopes, is present at $31 \%$ of plumes. Calculations of binary combinations of contaminant groups (as a percentage of plumes coded for the presence or absence of a contaminant group that is present with at least one other contaminant group) show that the most frequently occurring group is chlorinated hydrocarbons ( $2 / 3$ of all plumes), followed by tritium $(51 \%)$, isotopes and nitrates (both $45 \%)$, metals $(43 \%)$, sulfate $(31 \%)$, explosives $(10 \%)$, and fuel $(8 \%)$.

In ternary combinations, the most frequent contaminant groups are mixed wasteschlorinated hydrocarbons $(20.8 \%)$, radionuclides $(19.3 \%)$, and metals (15.6\%) (See Table S4a). This combination was also the most frequent in 1992 (18, Table 4) along with a combination of metals, anions, and radionuclides. A quaternary combination of contaminant groups most frequently includes mixed wastes - nitrates $(21.2 \%)$, metals $(18.3 \%)$, chlorinated hydrocarbons $(17.3 \%)$, and tritium (16.3\%) (See Table S4b). This combination is different from that identified in 1992 - metals, anions, radionuclides, and chlorinated hydrocarbons. The most frequent quinary combination of contaminant groups also contains mixed waste - metals, tritium, other radioactive isotopes, nitrates, and chlorinated hydrocarbons (See Table S4c).

Specific Contaminants. We calculated the frequency of occurrence of specific contaminants in multiple-contaminant groups as a percentage of: (a) all individual compounds in a given contaminant group, (b) a number of plumes containing the given contaminant group, and (c) a number of all plumes in the GWD.

Chlorinated hydrocarbons. The most common chlorinated hydrocarbons in the GWD were (in descending order, given as a percent of occurrence in all plumes): TCE- $57.5 \%, \mathrm{PCE}-31.7 \%$, DCE - 16.3\%, carbon tetrachloride (CT) - 15.8\%, and VC-8.1\% (Table S5a). These chlorinated hydrocarbons were also common in 1992 (18, Figure 7a).

Fuels and fuel components. No fuel component occurred in more than $5 \%$ of all plumes in the GWD, which seems low as discussed above. The most common fuel contaminants were benzene, diesel, jet fuel, MTBE, and toluene (Table S5b). In 1992, the most frequent fuel hydrocarbons were toluene, xylenes, benzene, ethylbenzene (18, Figure 8a).

Explosives. No explosive occurred in more than 5\% of all plumes in the GWD. The most frequent explosives were perchlorate, DNT (dinitrotoluene), HMX (high melting explosive, octahydro- 1.3,5.7-tetranitro-1,3,5,7-tetraazozine), RDX (royal demolition explosive/cyclonite/hexogen/cyclotrimethylene-trinitramine), trinitrobenzene (TNB), trinitrotoluene (TNT), and tertyl (Table S5c). In 1992, the following explosives (at a very few sites) were found-HMX, RDX, and trinitrotoluene (18, Table 5).

Metals. The metals occurred in more than 5\% of all plumes in the GWD, with the highest content ofchromium, molybdenum, and selenium, followed by arsenic, and lead at lower 
percentages (Table S5d). In 1992, the most common metals in groundwater (in descending order of occurrence) were lead, chromium, arsenic, zinc, and copper (18, Figure 5a);

Tritium and other radionuclides. The most common radionuclide in the GWD was tritium, ocurring in $38 \%$ of all plume in the GWD. Three other radionuclides ocurred in more than $5 \%$ of all the plumes are: uranium-19.5\%, strontium-10.9\%, and technetium-7.2\% (Table S5e). In 1992, the most common radionuclides were tritium, uranium, and strontium (18, Figure 6a), whereas technetium was ranked as the $7^{\text {th }}$ radionuclide.

Based on our analysis, out of 69 contaminants occurring in at least one of the plumes listed in the GWD, nine contaminants occur in more than $15 \%$ of the plumes in the GWD. These contaminants are (in descending order of occurrence): TCE, tritium, nitrates, PCE, sulfates, U, Cr, DCE and CT.

A comparison of the present data with those reported by Riley and Zachara (18) shows that the frequency of occurrence of individual contaminants has changed over the past decade. For example, technetium, CT, and MTBE were not significant contaminants in 1992, but they have recently become contaminants of concern at DOE facilities.

The frequency of occurrence of individual contaminants in binary combinations of contaminant groups is as follows (Table S6) is as follows:

(a) chlorinated hydrocarbons (including TCE, PCE, DCE, and CT) with nitrate and sulfates,

(b) chlorinated hydrocarbons (TCE and PCE) with tritium,

(c) chlorinated hydrocarbons (TCE and PCE) with metals (chromium),

(d) radioisotopes (tritium and uranium) with nitrate, (e) metals (chromium) with sulfate, and

(f) sulfate with nitrate.

Plume Volumes and Maximum Contaminant Concentrations. The GWD lists the volumes of 134 plumes, or $61 \%$ of the total 221 plumes. The plume volumes vary over approximately 6 orders of magnitude - from $5 \times 10^{4}$ to $3.5 \times 10^{10}$ gallons, with a mean value of $1.15 \times 10^{9}$ gallons (Table S7). The statistical distribution of plume volumes is close to lognormal (Figure S2). The total volume of 134 plumes is $1.54 \times 10^{11}$ gal $\left(5.85 \times 10^{11} \mathrm{~L}\right)$. Assuming that the remaining 87 plumes (with no volumes given in the GWD) are characterized by the same statistical distribution, the estimated total volume of contaminated groundwater would be $2.55 \times 10^{11} \mathrm{gal}$ $\left(9.65 \times 10^{11} \mathrm{~L}\right)$, i.e. approximately 1 trillion liters. This estimated volume of 221 plumes in the GWD exceeds the value of $1 \times 10^{10}$ gal $\left(3.79 \times 10^{10} \mathrm{~L}\right)$ given in the 1997 Federal Register, but it is about one half of that reported in $(20$, Pages 15 and 21$)-4.75 \times 10^{11}$ gal $\left(1.8 \times 10^{12} \mathrm{~L}\right)$. The estimated volume of 221 plumes in the GWD is 6.7 times less than the estimate of $1.7 \times 10^{12} \mathrm{gal}$ $\left(6.44 \times 10^{12} \mathrm{~L}\right)$ for 5,000 DOE plumes identified by the Subsurface Contaminants Focus Area (20). These comparisons are commensurate with our belief that the GWD is a significant sample of groundwater contamination in the DOE complex.

The distribution of the maximum contaminant concentrations for individual compounds detected in at least 10 groundwater plumes are given in Figures S3-S8. Because some concentration populations extend to the detection limit, the concentration distributions appear to 
be left-truncated. For the past decade, the ranges of PCE and TCE concentrations remained practically the same (Figure S3a). A normal quantile score (calculated as a probability corresponding to the normal distribution of quantile values) versus maximum concentrations of chlorinated hydrocarbons indicates that the DCE and, to a lesser extent, TCE distributions consist of two superimposed, lognormal distributions (Figure S4). This may be a result of the contribution from both primary contamination and degradation of PCE, and the DCE distribution could result from degradation of both PCE and TCE.

The $\mathrm{Cr}$ concentration distribution is lognormal and left truncated (Figures S3b and S6). The $\mathrm{Cr}$ concentration has essentially remained in the same range as that in 1992 (18). The lognormal and left truncated patterns are also typical for ${ }^{3} \mathrm{H}, \mathrm{Sr}$ and Tc activities (Figure S3b, Figure S7 and Table S8). The present maximum tritium concentration is approximately one order of magnitude higher than that a decade ago from (18). The present maximum $\mathrm{Sr}$ concentration in groundwater (Figure S3c) is more than two orders of magnitude greater than that reported 1992 (18). Figure S3b also shows the box-and-whiskers plot for technetium, which was not included in the 1992 report (18), and uranium, which had a one order higher minimum and maximum concentration than that reported in 1992.

The sulfate and, to a greater degree, nitrate concentration distributions (Figure S8) are relatively peaked and strongly positive kurtosis. The quartile plots of the maximum concentrations of sulfates and nitrates indicate that both distributions comprise of two parts: (a) low-concentration segments exhibiting a log-normal distribution, and (b) high-concentration segments departing from a log-normal distribution. For sulfates, the log-normal distribution segment likely represents background concentrations, whereas the high concentrations might be caused by groundwater contamination. The presence of low and high concentration segments of the nitrate distribution is likely to reflect different anthropogenic causes of groundwater contamination. For example, low concentrations could be caused by leakage of nitrates from sewage lines and agricultural releases, and higher concentrations could indicate discharges from fuel processing, uranium recovery, or fuel fabrication (19). Figure S3c shows that the present maximum concentration of nitrates in groundwater is lower by a factor of 2 than that in 1992 (18).

To assess a relative (apparent) risk of the groundwater plumes, we calculated a normalized concentration as a ratio given by

$$
C_{\mathrm{ci}}=\left(C-C_{\mathrm{st}}\right) /\left(C_{\max }-C_{\mathrm{st}}\right)
$$

where $C$ is the maximum contaminant concentration in a plume, $C_{\max }$ is the maximum contaminant concentration within a contaminant group, and $C_{\mathrm{st}}$ is the drinking water standard for this contaminant. $C_{\text {st }}$ is determined from various drinking water standards as shown in Table S11. The $C_{\mathrm{ci}}$ values vary from negative values, when the contaminant concentration is below $C_{\mathrm{st}}$, to 1 , which corresponds to the highest contaminant hazard of a particular contaminant. As an example, the plumes with the five largest estimates of $C_{\mathrm{ci}}$ for the five most prevalent chlorinated hydrocarbons are shown in Figure S9. For PCE, TCE, CT, and DCE only positive $C_{\mathrm{ci}}$ values are shown, because the scale of the vertical axis (apparent risk) is logarithmic. 
Maximum Contaminant Masses/Activities. The maximum contaminant masses/activities were calculated for plumes with known maximum concentrations and volumes from

$$
M_{\max }=C_{\max } * V
$$

where $C_{\max }$ is the maximum concentration/activity of a compound, and $V$ is the total plume volume. The total mass/activity for a contaminant and contaminant group is calculated as a sum of the masses/activities of calculated for each plume. For the plumes with either no reported concentration or volume, we estimated the maximum contaminant mass by assuming the same statistical distribution of concentrations (for a given contaminant) or volumes as for the plumes with the known information. The results are summarized in Tables S9 and S10.

The contaminant masses above the regulatory limits were calculated from the formula

$$
M_{\text {max, reg }}=\left(C_{\max }-C_{\text {reg }}\right)^{*} V
$$

where $M_{\max \text {, reg }}$ is the maximum estimate of the mass/activity of each compound, and $C_{\text {reg }}$ is the regulatory limit (Table S11). The regulatory limits were chosen for calculations according to the following precedence: Maximum Contaminant Limit (MCL), California Maximum Contaminant Limit (CA MCL), Treatment Technology (TT), California Response Limit (CA RL), Secondary Drinking Water Standard (SDWS), California Secondary Drinking Water Standard (CA SDWS). For contaminants without a regulatory limit (designated in Table S11 with an asterisk, *) no limit-corrected mass/activity was calculated. For contaminants with no concentration and volume data in the database (designated with a double asterisk, **) no mass/activity was calculated. Note from Tables S9 and S10 that the contaminant masses and activities above the regulatory limits are not significantly different from the total masses and activities.

The ranking of contaminant masses (as a percentage of the total contaminant mass) at all DOE sites is as follows: nitrates - 55\%, chlorinated hydrocarbons $-23 \%$ (including TCE $-17 \%$ and PCE-6\%), sulfates-15\%, PCE-6\%, diesel-5\%. According to the statistics of radioactive activities, virtually $100 \%$ of the total activity is attributed to tritium. Note the ranking according to occurrence is different than the ranking according to mass. For instance nitrates are the fourth ranked contaminant group by occurrence, but the first ranked group by contaminant mass. Isotopes are the second ranked group by occurrence, but virtually $100 \%$ of the total activity is due to tritium. The five largest sites by estimated maximum contaminant group mass $(\mathrm{kg})$ or activity (pCi) are given in Figure 3.

Multiple Factor Analysis and $\boldsymbol{k}$-means Clustering of the Groundwater Plumes. To assess the complexity and to integrate the different groundwater plume characteristics (Tables S1 and S12) we used a multiple factor analysis, MFA (22) followed by a $k$-means cluster analysis of main factors characterizing groundwater plumes. The approach and the results of this analysis are given in Section S3 in Supporting Information. Based on the basic plume characteristics, the plumes are classified into 5 clusters as given in Tables S13h,i. Using the basic plume characteristics together with the CT concentrations, the plumes are classified into 5 clusters as given in Tables S14g,h.

We suggest using the quantitative information about the individual contaminants and contaminant mixtures in decision making to establish priorities to advance the basic research on 
environmental problems and developing remediation technologies for groundwater plumes throughout the DOE complex. The data analysis presented in this report could be of value to environmental managers, stakeholders, funding sources, site operators, the R\&D community, as well as other interested parties.

\section{Acknowledgments}

This project was supported by the Environmental Remediation Science Division, Office of Sciences, U.S. Department of Energy. Lawrence Berkeley National Laboratory is operated Contract No. DE-AC02-05CH11231 with DOE. We are thankful to Blaine Rowley of DOE for providing us the DOE Groundwater Database in the Access format and for his gracious patience answering our many questions about its content.

\section{Supporting Information is available free of charge via the internet at http://pubs.acs.org.}

\section{Literature Cited}

(1) U.S. Department of Energy/Environmental Management Report to Congress on Long-Term Stewardship, DOE/EM-0563, January 2001, Volume I - Summary Report, 2001. Available at http://lts.apps.em.doe.gov/center/reports/pdf/SS_VolI.pdf

(2) U.S. Department of Energy, 2006, Department of Energy Five Year Plan, FY 2007-FY 2011, Environmental Management, Office of the Chief Financial Officer Volume II, March 2006. Available at http://www.em.doe.gov/PDFs/170016EM FYP Final 3-606.pdf

(3) U.S. Department of Energy, 1999, From Cleanup to Stewardship, a Companion Report to Accelerating Cleanup. Available at http://www.em.doe.gov/pdfs/doc130.pdf

(4) U.S. Department of Energy, 1998, Accelerating Cleanup: Paths to Closure, DOE/EM-0362, June 1998. Available at http://www.em.doe.gov/Publications/accpath.aspx

(5) Nuclear Waste Policy Act of 1982. Available at http://epw.senate.gov/nwpa82.pdf

(6) U.S. Environmental Protection Agency. Cleaning Up the Nation's Waste Sites: Markets and Technology Trends, EPA 542-R-04-015, 2004. Available at http://www.cluin.org/download/market/2004market.pdf

(7) McCune, M. C.; Brin, G. L., Sharing expertise and technologies in deactivating and decommissioning DOE's contaminated excess facilities, WM'01 Conference, February 25-March 1, 2001, Tucson, AZ, 2001. 
(8) U.S. Department of Energy, Office of Science Strategic Plan, February 2004. Available at http://www.er.doe.gov/Sub/Mission/Mission_Strategic.htm

(9) U.S. Department of Energy. Cleanup Criteria/Decision Document (C2D2) Database. Available at http://c2d2.eml.doe.gov/index.cfm

(10) U.S. Department of Energy, Central Information Database (CID). Available at http://cid.em.doe.gov/

(11) A Report to Congress on Long-Term Stewardship, Volume I-Summary Report. Office of Environmental Management, Office of Long-Term Stewardship. DOE/EM-0563. January 2001. Washington, D.C.: U.S. Department of Energy. Available at http://lts.apps.em.doe.gov/center/ndaareport.html

(12) U.S. Environmental Protection Agency, Record of Decision (ROD) database. Available at http://www.epa.gov/superfund/sites/rods/index.htm,

(13) Cleanup Level Corporation database. Available at http://www.cleanuplevel.com/

(14) Fountain, J. C., Technologies for Dense Nonaqueous Phase Liquid Source Zone Remediation, Technology Evaluation Report, TE-98-02, 1998. Available at http://www.clu-in.org/download/toolkit/e dnapl.pdf

(15) U.S. Environmental Protection Agency, Abstracts of Remediation, Case Studies, Volume 5, EPA 542-R-01-008, May 2001. Available at http://www.cluin.org/download/frtr/factshee.pdf

(16) U.S. Department of Energy, Groundwater Data Base, 2003. Dated 4-22-03. Available at http://www.em.doe.gov/pages/groundwatersoildatabase.aspx

(17) Groundwater and Soil Cleanup: Improving Management of Persistent Contaminants, National Research Council, National Academy Press, Washington, D.C., 1999. Available at http://books.nap.edu/openbook.php?isbn=0309065496

(18) Riley R.G. and J.M. Zachara, Chemical Contaminants on U.S. Department of Energy Lands and Selection of Contaminant Mixtures for Subsurface Science Research. Pacific Northwest Laboratory, DOE/ER-0547T, April 1992. Available at http://www.osti.gov/energycitations/product.biblio.jsp?osti id=10147081

(19) Stenner, R.D., K.H. Cramer, K.A. Higley, S.J. Jette, D.A. Lamar, T.J. McLaughlin, D.R. Sherwood, and N.C. Van Houten. Hazard Ranking System Evaluation of CERCLA Inactive Waste Sites at Hanford: Evaluation Methods and Results. PNL-6456, Volumes 1 and 2, Pacific Northwest Laboratory, Richland, WA, 1988. Available at http://www.osti.gov/bridge/product.biblio.jsp?osti_id=6849042 
(20) U.S. Department of Energy FY 2002 Congressional Budget. Available at http://www.cfo.doe.gov/budget/02budget/defem/all_oth.pdf

(21) Greenacre, M.; Blasius, J. Multiple Correspondence Analysis and Related Methods, Chapman \& Hall/CRC Statistics in the Social and Behavioral Science. Vol.1. 2006. 


\title{
Supporting Information
}

\section{Complexity of Groundwater Contaminants at DOE Sites}

\author{
Terry C. Hazen ${ }^{\mathbf{1}, 2}$, Boris Faybishenko ${ }^{1}$, and Preston Jordan ${ }^{1}$ \\ ${ }^{1}$ Lawrence Berkeley National Laboratory, Earth Sciences Division, Berkeley, CA 94720 \\ ${ }^{2}$ Virtual Institute for Microbial Stress and Survival, http://vimss.lbl.gov
}

The file "Supporting Information” includes:

S1. Assumptions and uncertainties - 1 page.

S2. Corroboration of the GWD (2003) data using the LBNL Records-1 page.

$\mathrm{S} 3$. Multiple factor analysis and $k$-means clustering of the groundwater plumes -2 pages, 14 Tables and 11 Figures. 


\section{S1. Assumptions and uncertainties}

We assume that the GWD records are representative of the concentrations of contaminants present in multi-contaminant plumes, for which several types of chemical reactions could typically occur. The sources of uncertainty in the results of the DOE GWD data analysis, as compared to the actual situation, is inconsistency in the data collection from different sites located in various climatic conditions, a partial representation of all DOE sites, and the difference in site characterization technologies.

Maximum concentration/activity and plume volume are available for many plumes in the GWD. For a given plume, the GWD does not include concentration/activity data other than the maximum concentration. In this paper, the total mass/activity of a contaminant in a plume was calculated by multiplying the plume volume by the maximum concentration/activity. This approach overestimates the contaminant mass/activity as a result of many simplifying assumptions. The approach does not take into account the actual concentrations/activities throughout the plume, which are almost always lower than the maximum concentration/activity. The approach does not take into the portion of the plume volume occupied by single contaminants in multi-contaminant plumes. Despite these significant limitations, the simplified approach provides a "first cut" comparison of contaminant predominance in the DOE complex on a mass/activity basis using the data available in the GWD. These total masses/activities should not be taken as representative of the actual masses/activities, though, and were calculated purely to provide relative comparisons between contaminants on a mass/activity basis. The uncertainty in calculations of contaminant masses/activities could be caused by the lack of information on the spatial distribution of contaminant concentrations within a plume. For example, using the entire plume volumes (rather than the volume occupied by a particular contaminant) and maximum contaminant concentrations (the maximum concentration exceeds real values at the plume edges), which are listed in the database, we are likely to overestimate the contaminant mass/activity. 


\section{S2. Corroboration of the GWD (2003) data using the LBNL Records}

To assess the reliability of the GWD, we compared the LBNL records entered in the GWD (2003) with those from LBNL's Environmental Restoration Program (ERP) database, including the number of plumes, contaminant groups, contaminants in each plume, and maximum concentrations (LBNL, 2000, 2002, 2003). We found that the records in the GWD generally match the ERP records from the time period from the $4^{\text {th }}$ Quarter of Federal Fiscal Year 2001 (July $1^{\text {st }}, 2001$ ) through the $4^{\text {th }}$ Quarter of Federal Fiscal Year 2002 (September $30^{\text {th }}, 2002$ ). This comparison also indicates an accurate data entry (for this period) to the GWD. We found that the plume areas in the GWD generally match the actual areas determined at the LBNL sites. However, the plume volumes in the GWD and calculated using the actual LBNL aquifer thickness and porosity data are different by a factor from $1 / 8$ to 3 .

To assess the degree of overestimating the calculated contaminant masses/activities, using the assumption of an evenly contaminant distribution over the entire plume volume, we used the results of observations of the chlorinated hydrocarbons at the Old Town plume of LBNL (LBNL, 2000). We estimated that individual chlorinated hydrocarbons occurred in $1 \%$ to $89 \%$ of the total plume area, with a median value of approximately $20 \%$. We determined that the higher the contaminant concentration relative to other contaminants, the higher the proportion of the plume occupied by the contaminant. The analysis of the Old Town plume at LBNL indicates that the assumption of the evenly distributed contaminant concentrations over the entire plume may be applicable for the high contaminant concentrations, but is likely to lead to the overestimation of the mass of lower concentration contaminants by a factor from 100 to $200-400$.

\section{Literature cited in Section S2}

LBNL, 2000. Draft Final RCRA Facility Investigation Report, Environmental Restoration Program, Lawrence Berkeley National Laboratory, Berkeley, California, September 2000.

LBNL, 2002. Quarterly Progress Report, $2^{\text {nd }}$ Quarter Fiscal Year 2002 (January 1 to March 31, 2002 for the LBNL Hazardous Waste Facility Permit, Lawrence Berkeley National Laboratory, Berkeley, California, August 2002.

LBNL, 2003. Quarterly Progress Report, 2 ${ }^{\text {nd }}$ Quarter Fiscal Year 2003 (January 1 to March 31, 2002 for the LBNL Hazardous Waste Facility Permit, Lawrence Berkeley National Laboratory, Berkeley, California, August 2003. 


\section{S3. Multiple Factor Analysis and $k$-means Clustering of the Groundwater Plumes}

The groups of plume characteristics were classified as main or supplementary for the MFA. The basic analysis included the following 5 groups of groundwater plume characteristics (see Table S1):

Group 1. Identification of the presence (identified as 1) or absence (identified as 0 ) of contaminant groups.

Group 2. Two categories of data are included in this group:

(a) Number of contaminant groups (Ngr) that are present at the site, and

(b) Contamination severity index (Sv), which we defined depending on the severity of contamination and complexity of remediation:

1-sulfates $\left(\mathrm{SO}_{4}\right)$ and/or nitrates $\left(\mathrm{NO}_{3}\right), 2-\mathrm{CVOCs}$ and/or fuels $(\mathrm{Fl})$, 4-explosives (Expl), 8-tritium (H3), and 16-metals (M) and/or radioisotopes (RI).

Group 3. Plume volumes (Vol), which are expressed as $\log 10$ of the plume volume (given in gallons),

Group 4. Plume depths (Dp) and velocities (Vel), which are expressed as log10 of the plume depth (ft) and velocity (ft/yr), and

Group 5. Climatic conditions, which were identified as dry or moist, using the identifiers 1 and 2, respectively (according to the map of DOE's climate zoneshttp://www.energycodes.gov/implement/pdfs/color map climate zones Mar03.pdf

Groups 1, 2, and 3 are considered the main plume characteristics, and the Groups 4 and 5 are supplementary ones. Table S12 summarizes data groups used in the MFA calculations. In addition to the aforementioned analysis of 5 basic groups of plume characteristics, we also analyzed the carbon tetrachloride (CT) concentrations.

The CT data were presented as a ratio of its concentration in groundwater to the MCL. The results of the MFA and cluster analysis are summarized in Table S13 and Figure S9 for basic plume characteristics. The correlation matrix of the quantitative variables shows the overall low correlation between the various plume characteristics (Tables S13c). The correlation coefficient between the number of contaminant groups and the severity index is 0.583 for 124 plumes used for the analysis of the basic plume characteristics. From the results of the MFA, the variability of the basic plume characteristics can mostly be described by the first four factors (their cumulative variability is about 70\%) (Figure S10a). 
Table S13g and Figure S10b provide the contributions of different groups of data to the multiple factors. The contaminant severity and the number of contaminant groups provide a major contribution to the $1^{\text {st }}$ factor. The types of contaminant groups and CT concentrations provide the major contribution to the $2^{\text {nd }}$ factor. The contribution of the supplementary data (climate and plume depth and velocity) is insignificant. The $1^{\text {st }}$ factor is mostly related to the presence of radioactive contaminants, and the $2^{\text {nd }}$ factor is mostly related to the presence of sulfates, and to a lesser degree the presence of nitrates and metals.

The relationships between the groups of variables can be performed using the $\mathrm{L}_{\mathrm{g}}$ and $\mathrm{RV}$ coefficients. The $\mathrm{L}_{\mathrm{g}}$ coefficient is defined as the scalar product between the matrices associated with each group; the Lg of 0 corresponds to no relationship between the groups, and it increases when the relationship between the groups becomes stronger. The RV coefficient is defined as the quotient of the $\mathrm{L}_{\mathrm{g}}$ coefficient and is determined as the product of the norms of the matrices associated with each group; the RV coefficients vary from 0 (no relationship between the groups) to 1 (a strong relationship between the groups) (Greenacre and Blasius. 2006). The strongest relationship is, as expected, between the types of contaminant groups and the contamination severity. The relationships between contaminant groups and the plume depth/velocity, and contaminant groups and climate are weak, and there is no a significant relationship with the plume volume. The $k$-means analysis was conducted using the first four factors of the MFA for the basic plume characteristics. The plumes classified into 5 clusters as given in Tables S13h,i.

As an example of the MFA and the cluster analysis using the concentration data, we analyzed the $\mathrm{CT}$ concentrations combined with the aforementioned 5 groups of basic plume characteristics. The $\mathrm{CT}$ data were presented as a ratio of $\mathrm{CT}$ concentration in groundwater to the MCL of CT. The CT group was identified as a main and quantitative group of data. The results of the MFA and $k$-means analysis including the CT concentration data are shown in Table S14 and Figure S11. The variability of basic plume characteristics and CT concentrations can be mostly described by the first three factors - cumulative variability exceeds 70\% (Table S14d and Figure S11a). The correlation coefficient between the number of contaminant groups and the severity index 0.563 for 26 plumes used in the analysis of CT concentrations. The best correlation is between the plume depths and groundwater velocity. The correlation between the CT concentration and basic plume characteristics is low. Based on the $k$-means analysis of the first three factors of the MFA for the basic plume characteristics combined with $\mathrm{CT}$ concentration data, the plumes are classified into 5 clusters as given in Tables S14g,h.

\section{Literature cited in Section S3}

Greenacre and Blasius. 2006. Multiple Correspondence Analysis and Related Methods, Chapman \& Hall/CRC Statistics in the Social and Behavioral Science. Volume 1. 
Table S1. Data used in the MFA and cluster analysis of groundwater plume characteristics (see abbreviations at the bottom of the table)

\begin{tabular}{|c|c|c|c|c|c|c|c|c|c|c|c|c|c|c|c|c|c|c|}
\hline Plume name & Plume code & VOCs & $\mathbf{F I}$ & $\operatorname{Exp}$ & $\bar{M}$ & Mt & \begin{tabular}{l|l}
$\mathrm{H} 3$ \\
\end{tabular} & $\mathbf{R}$ & SO4 & $\mathrm{NO3}$ & $3 \mathrm{Nc}$ & $\operatorname{lgr}$ & Sv & Vol & Dp & Vel & $\mathbf{C l}$ & $\mathrm{CCl} 4$ \\
\hline $\begin{array}{l}\text { Albuquerque Inhalation } \\
\text { Toxicology Laboratory - } \\
\text { Lagoon }\end{array}$ & 11 & 0 & 0 & 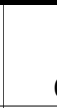 & 0 & 0 & 0 & 0 & 1 & 0 & 0 & 1 & 1 & 7.59 & 2.19 & 1.94 & 1 & \\
\hline $\begin{array}{l}\text { Albuquerque Inhalation } \\
\text { Toxicology Laboratory - } \\
\text { Diesel }\end{array}$ & 12 & 0 & 1 & ( & 0 & 0 & 0 & 0 & 0 & 0 & 0 & 1 & 2 & 5.88 & 2.19 & 1.94 & 1 & \\
\hline Ambrosia Lake & 133 & 0 & 0 & ( & 0 & 1 & 0 & 1 & 0 & 1 & 1 & 3 & 16 & & 2.00 & 1.18 & 1 & \\
\hline Amchitka - Long Shot & 8 & 0 & 0 & ( & 0 & 1 & 1 & 1 & 0 & 0 & 0 & 3 & 16 & & 3.36 & 1.00 & 2 & \\
\hline Amchitka- Milrow & 9 & 0 & 0 & & 0 & 1 & 1 & 1 & 0 & 0 & 0 & 3 & 16 & & 3.60 & 1.00 & 2 & \\
\hline Amchitka - Cannikin & 10 & 0 & 0 & 7 & 0 & 1 & 1 & 1 & 0 & & 0 & 3 & 16 & & 3.77 & 1.00 & 2 & \\
\hline Argonne Lab - 317 & 6 & 1 & 0 & ( & 0 & 0 & 0 & 0 & 0 & 0 & 0 & 1 & 2 & 6.95 & 1.54 & 1.57 & 1 & \\
\hline Argonne Lab - 319 & 7 & 1 & 0 & 7 & 0 & 0 & 1 & 0 & 0 & 0 & 0 & 2 & 8 & 6.60 & 1.30 & 1.57 & 1 & \\
\hline Ashtabula & 134 & 1 & 0 & ( & 0 & 1 & 0 & 1 & 1 & & 1 & 5 & 16 & 6.18 & 1.48 & 0.60 & 2 & \\
\hline BNL - OU V VOC & 13 & 1 & 0 & 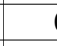 & 0 & 1 & 1 & 0 & 0 & 0 & 0 & 3 & 16 & 7.58 & 2.18 & 2.48 & 2 & \\
\hline BNL -Sr90 - Chemical Holes & 14 & 0 & 0 & ( & 0 & 0 & 0 & 1 & 0 & 0 & 0 & 1 & 16 & 7.22 & 1.48 & 1.40 & 2 & \\
\hline BNL -HFBR Tritium & 15 & 1 & 0 & trat & 0 & 0 & 1 & 0 & 0 & 0 & 0 & 2 & 8 & 6.95 & 1.70 & 2.48 & 2 & \\
\hline BNL -OU I VOC & 178 & 1 & 0 & & 0 & 0 & 1 & 1 & 0 & 0 & 0 & 3 & 16 & 8.77 & 1.30 & 2.48 & 2 & \\
\hline BNL -OU I/IV VOC & 179 & 1 & 0 & 3 & 0 & 0 & 1 & 0 & 0 & 0 & 0 & 2 & 8 & 7.47 & 1.85 & 2.48 & 2 & \\
\hline BNL -Sr-90 - BGGR & 180 & 1 & 0 & ( & 0 & 0 & 0 & 1 & 0 & 0 & 0 & 2 & 16 & 8.65 & 1.78 & 1.40 & 2 & \\
\hline BNL -Sr-90 Former HWMF & 181 & 1 & 0 & 7 & 0 & 0 & 1 & 1 & 0 & 0 & 0 & 3 & 16 & 8.86 & 1.30 & 1.40 & 2 & \\
\hline BNL -OU VI VOC & 189 & 1 & 0 & 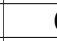 & 0 & 0 & 0 & 0 & 0 & 0 & 0 & 1 & 2 & 8.30 & 1.95 & 2.48 & 2 & \\
\hline $\begin{array}{l}\text { BNL -Sr-90 Waste } \\
\text { Concentration Facility }\end{array}$ & 190 & 1 & 0 & ( & 0 & 0 & 1 & 1 & 0 & 0 & 0 & 3 & 16 & 8.53 & 1.48 & 1.40 & 2 & \\
\hline BNL -OU III VOC & 191 & 1 & 0 & & 0 & 0 & 1 & 0 & 0 & 0 & 0 & 2 & 8 & 9.73 & 1.70 & 2.48 & 2 & \\
\hline Canonsburg & 135 & 0 & 0 & & 0 & 1 & 0 & 1 & 0 & 0 & 0 & 2 & 16 & 7.77 & 1.30 & & 2 & \\
\hline Central Nevada Test Area & 16 & 0 & 0 & - & 0 & 1 & 1 & 1 & 0 & 0 & 0 & 3 & 16 & 8.30 & 3.51 & 2.00 & 1 & \\
\hline Durango & 136 & 0 & 0 & ( & 0 & 1 & 0 & 1 & 0 & 0 & 0 & 2 & 16 & 7.73 & 2.00 & & 1 & \\
\hline ETEC-1, FSDF & 17 & 1 & 1 & - & 0 & 1 & 1 & 1 & 0 & 0 & 0 & 5 & 16 & 7.48 & 2.48 & 1.70 & 1 & \\
\hline ETEC-2, Bldg. 56 Landfill & 18 & 1 & 0 & 7 & 0 & 1 & 0 & 1 & 0 & 0 & 0 & 3 & 16 & 10.54 & 2.48 & 1.70 & 1 & \\
\hline ETEC-3, RMHF & 19 & 1 & 0 & T & 0 & 1 & 1 & 1 & 0 & 0 & 0 & 4 & 16 & 10.41 & 2.36 & 1.70 & 1 & \\
\hline Falls City & 137 & 0 & 0 & ( & 0 & 1 & 0 & 1 & 0 & 1 & 1 & 3 & 16 & & 2.30 & 2.30 & 2 & \\
\hline Fernald-Great Miami Aquifer & 138 & 1 & 0 & 7 & 0 & 1 & 0 & 1 & 0 & 1 & 1 & 4 & 16 & 9.30 & & 3.00 & 2 & \\
\hline Gasbuggy & 20 & 0 & 0 & & 0 & 1 & 1 & 1 & 0 & 0 & 0 & 3 & 16 & 10.30 & 3.63 & 0.00 & 1 & \\
\hline Gnome-Coach & 21 & 0 & 0 & - & 0 & 1 & 1 & 1 & 0 & 0 & 0 & 3 & 16 & 8.60 & 3.08 & 2.00 & 1 & \\
\hline Grand Junction Project Office & 141 & 0 & 0 & t & 0 & 1 & 0 & 1 & 0 & 0 & 0 & 2 & 16 & 9.00 & & & 1 & \\
\hline Grand Junction (UMTRA) & 142 & 0 & 0 & 7 & 0 & 1 & 0 & 1 & 0 & & 0 & 2 & 16 & 7.64 & 1.70 & & 1 & \\
\hline Green River & 143 & 0 & 0 & T & 0 & 1 & 0 & 1 & 0 & 1 & 1 & 3 & 16 & 7.40 & 1.48 & 2.48 & 1 & \\
\hline Gunnison & 144 & 0 & 0 & ( & 0 & 1 & 0 & 1 & 0 & 0 & 0 & 2 & 16 & 6.00 & 2.00 & 2.30 & 1 & \\
\hline Hanford - 100-HR-3 (H) & 22 & 0 & 0 & ( & 0 & 1 & 1 & 1 & 0 & 1 & 1 & 4 & 16 & 6.18 & 2.00 & 3.70 & 1 & \\
\hline $\begin{array}{l}\text { Hanford - 100-HR-3 (D/DR } \\
\text { Area) }\end{array}$ & 23 & 0 & 0 & ( & 0 & 1 & 1 & 0 & 1 & 0 & 0 & 3 & 16 & 6.00 & 2.00 & 3.70 & 1 & \\
\hline Hanford - 100-KR-4 & 24 & 0 & 0 & 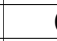 & 0 & 1 & 1 & 1 & 0 & 1 & 1 & 4 & 16 & 7.00 & 2.00 & 3.70 & 1 & \\
\hline Hanford - 100-NR-2 & 25 & 0 & 1 & ( & 0 & 1 & 1 & 1 & 1 & 1 & 1 & 6 & 16 & 6.60 & 2.00 & 3.70 & 1 & \\
\hline Hanford - 200-UP-1 & 26 & 1 & 0 & ( & 0 & 0 & 1 & 1 & 0 & 1 & 1 & 4 & 16 & 5.95 & 2.40 & 3.00 & 1 & 130 \\
\hline Hanford - 200-ZP-1 & 27 & 1 & 0 & ( & 0 & 0 & 1 & 1 & 0 & & 1 & 4 & 16 & 5.70 & 2.40 & 3.00 & 1 & 6900 \\
\hline Hanford - 100-BC-5 & 28 & 0 & 0 & trat & 0 & 1 & 1 & 1 & 0 & 1 & 1 & 4 & 16 & 5.13 & 2.00 & 2.30 & 1 & \\
\hline Hanford - 200-BP-5 & 29 & 0 & 0 & 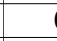 & 0 & 0 & 1 & 1 & 0 & 1 & 1 & 3 & 16 & 5.13 & 2.40 & 3.07 & 1 & \\
\hline Hanford - 300-FF-5 & 30 & 1 & 0 & ( & 0 & 0 & 1 & 1 & 0 & 1 & 1 & 4 & 16 & 5.88 & 2.00 & 3.70 & 1 & \\
\hline Hanford - 100-FR-3 & 31 & 1 & 0 & ( & 0 & 1 & 1 & 1 & 0 & 1 & 1 & 5 & 16 & 7.94 & 2.00 & 3.22 & 1 & \\
\hline Hanford - 200-PO-1 & 32 & 0 & 0 & ( & 0 & 1 & 1 & 1 & 0 & 1 & 1 & 4 & 16 & 7.85 & 2.40 & 3.00 & 1 & \\
\hline INL - WAG-1 & 33 & 1 & 0 & & 0 & 0 & 1 & 1 & 0 & 0 & 0 & 3 & 16 & 7.47 & 2.32 & 3.30 & 1 & \\
\hline INL - WAG-2 & 34 & 0 & 0 & ( & 0 & 1 & 1 & 0 & 0 & 0 & 0 & 2 & 16 & 7.55 & 1.90 & 3.30 & 1 & \\
\hline INL - WAG-3 & 35 & 0 & 0 & 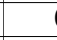 & 0 & 0 & 1 & 1 & 0 & 0 & 0 & 2 & 16 & 8.39 & 2.65 & 3.30 & 1 & \\
\hline INL - WAG-4 & 36 & 0 & 0 & 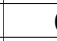 & 0 & 0 & 1 & 0 & 1 & 1 & 1 & 3 & 8 & 7.21 & 2.81 & 3.30 & 1 & \\
\hline INL - WAG-7 & 37 & 1 & 0 & ( & 0 & 0 & 1 & 1 & 0 & & 0 & 3 & 16 & 7.10 & 2.78 & 3.30 & 1 & 6 \\
\hline
\end{tabular}




\begin{tabular}{|c|c|c|c|c|c|c|c|c|c|c|c|c|c|c|c|c|}
\hline Kansas Plant - Blue River & 38 & 1 & 1 & 0 & 0 & 0 & 0 & 0 & 0 & 2 & 2 & 7.77 & 1.48 & 3.48 & 2 & \\
\hline Kansas Plant - Indian Creek & 39 & 1 & 0 & 0 & 0 & 0 & 0 & 0 & 0 & 1 & 2 & 5.83 & 1.60 & 3.06 & 2 & \\
\hline Lakeview & 145 & 0 & 0 & 0 & 1 & 0 & 0 & 1 & 0 & 2 & 16 & 6.88 & 1.60 & 2.30 & 1 & \\
\hline LBNL - B-51/64 & 41 & 1 & 1 & 0 & 1 & 0 & 0 & 0 & 0 & 3 & 16 & 8.14 & 1.00 & 1.00 & 1 & 12 \\
\hline LBNL - B-71 & 42 & 1 & 0 & 0 & 0 & 0 & 0 & 0 & 0 & 1 & 2 & 8.31 & 1.30 & 1.00 & 1 & \\
\hline LBNL - B-7E & 43 & 0 & 1 & 0 & 0 & 0 & 0 & 0 & 0 & 1 & 2 & 6.53 & 1.40 & 1.00 & 1 & \\
\hline LBNL - Old Town & 44 & 1 & 1 & 0 & 0 & 0 & 0 & 0 & 0 & 2 & 2 & 8.08 & 1.48 & 1.00 & 1 & 3422 \\
\hline LBNL - B-75 & 45 & 1 & 0 & 1 & 0 & 1 & 0 & 0 & 0 & 3 & 8 & 8.05 & 1.48 & 1.70 & 1 & \\
\hline LBNL - B-74 & 46 & 0 & 1 & 0 & 0 & 0 & 0 & 0 & 0 & 1 & 2 & 7.80 & 1.08 & 1.70 & 1 & \\
\hline LBNL - B-37 & 47 & 1 & 0 & 0 & 0 & 0 & 0 & 0 & 0 & 1 & 2 & 8.29 & 1.48 & 1.00 & 1 & \\
\hline LBNL - Test Lab/Central Lab & & & & & & & & & & & & & & & & \\
\hline Area & 226 & 1 & 0 & 0 & 0 & 0 & 0 & 0 & 0 & 1 & 2 & 7.52 & 1.08 & 1.70 & 1 & \\
\hline LBNL - B-51L & 227 & 1 & 1 & 0 & 0 & 0 & 0 & 0 & 0 & 2 & 2 & 6.67 & 1.08 & 1.70 & 1 & \\
\hline LBNL - B-76 Area & 228 & 1 & 1 & 0 & 0 & 1 & 0 & 0 & 0 & 3 & 8 & 7.84 & 1.30 & 1.00 & 1 & \\
\hline LLNL -TFA-1B & 48 & 1 & 0 & 0 & 1 & 0 & 0 & 1 & 0 & 3 & 16 & 7.14 & 2.10 & 1.85 & 1 & \\
\hline LLNL -TFB-1B & 49 & 1 & 0 & 0 & 1 & 0 & 0 & 0 & 0 & 2 & 16 & 7.62 & 1.90 & 1.85 & 1 & 2 \\
\hline LLNL -TFC-SE-1B & 50 & 1 & 0 & 0 & 1 & 0 & 0 & 0 & 0 & 2 & 16 & 7.62 & 1.95 & 1.85 & 1 & \\
\hline LLNL -TFD-W-1B & 51 & 1 & 0 & 0 & 1 & 0 & 0 & 1 & 0 & 3 & 16 & 7.03 & 1.78 & 1.78 & 1 & \\
\hline LLNL -TFE-E-2 & 52 & 1 & 0 & 0 & 0 & 1 & 0 & 1 & 1 & 4 & 8 & 7.47 & 2.00 & 1.85 & 1 & \\
\hline LLNL -TF5475N-3A & 53 & 1 & 0 & 0 & 0 & 1 & 0 & 0 & 0 & 2 & 8 & 7.21 & 1.98 & 1.60 & 1 & 27 \\
\hline LLNL -TF5475-S-3A & 54 & 1 & 0 & 0 & 0 & 1 & 0 & 0 & 0 & 2 & 8 & 7.24 & 2.02 & 1.60 & 1 & 14 \\
\hline LLNL -TFG-1B & 55 & 1 & 0 & 0 & 1 & 1 & 0 & 0 & 0 & 3 & 16 & 6.87 & 2.00 & 1.85 & 1 & \\
\hline LLNL -B292-1B & 56 & 0 & 0 & 0 & 0 & 1 & 0 & 0 & 0 & 1 & 8 & 6.86 & 1.70 & 1.60 & 1 & \\
\hline LLNL -T5475-2 & 57 & 1 & 0 & 0 & 1 & 1 & 0 & 1 & 0 & 4 & 16 & 7.63 & 2.00 & 1.85 & 1 & 3 \\
\hline LLNL -TF518-5 & 58 & 1 & 0 & 0 & 1 & 1 & 0 & 1 & 1 & 5 & 16 & 7.65 & 2.02 & 1.85 & 1 & 150 \\
\hline LLNL -TFA-2 & 192 & 1 & 0 & 0 & 1 & 0 & 0 & 1 & 0 & 3 & 16 & 7.32 & 2.18 & 1.85 & 1 & \\
\hline LLNL -TFA-3A & 193 & 1 & 0 & 0 & 1 & 0 & 0 & 1 & 1 & 4 & 16 & 6.05 & 2.26 & 1.65 & 1 & 3 \\
\hline LLNL -TFB-2 & 194 & 1 & 0 & 0 & 1 & 0 & 0 & 1 & 1 & 4 & 16 & 6.92 & 2.18 & 1.85 & 1 & \\
\hline LLNL -TFC-1B-TCE & 195 & 1 & 0 & 0 & 1 & 0 & 0 & 1 & 1 & 4 & 16 & 7.97 & 1.95 & 1.85 & 1 & \\
\hline LLNL -TFD-NE-2 & 196 & 1 & 0 & 0 & 0 & 0 & 0 & 1 & 0 & 2 & 2 & 7.43 & 2.13 & 1.78 & 1 & \\
\hline LLNL -TFD-ETC-N-2 & 197 & 1 & 0 & 0 & 0 & 0 & 0 & 1 & 1 & 3 & 2 & 6.61 & 1.98 & 1.85 & 1 & 10 \\
\hline LLNL -TFD-SE-2 & 198 & 1 & 0 & 0 & 0 & 0 & 0 & 1 & 1 & 3 & 2 & 7.65 & 2.02 & 1.85 & 1 & \\
\hline LLNL -TFD-NE-3A & 199 & 1 & 0 & 0 & 0 & 0 & 0 & 1 & 0 & 2 & 2 & 7.17 & 2.15 & 1.78 & 1 & \\
\hline LLNL -TFD-ETC-S-3A & 200 & 1 & 0 & 0 & 0 & 0 & 0 & 1 & 1 & 3 & 2 & 6.63 & 2.06 & 1.70 & 1 & 1 \\
\hline LLNL -TFD-S-3A & 201 & 1 & 0 & 0 & 1 & 0 & 0 & 1 & 1 & 4 & 16 & 6.97 & 2.19 & 1.70 & 1 & \\
\hline LLNL -TFD-ETC-N-3A/3B & 202 & 1 & 0 & 0 & 0 & 0 & 0 & 1 & 0 & 2 & 2 & 9.87 & 2.08 & 1.70 & 1 & 89 \\
\hline LLNL -TFD-3B & 203 & 1 & 0 & 0 & 0 & 1 & 0 & 1 & 1 & 4 & 8 & 7.80 & 2.18 & 1.70 & 1 & 8 \\
\hline LLNL -TFD-HEL-3B & 204 & 1 & 0 & 0 & 0 & 0 & 0 & 1 & 1 & 3 & 2 & 8.93 & 2.08 & 1.48 & 1 & 22 \\
\hline LLNL -TFD-HEL-4 & 205 & 1 & 0 & 0 & 1 & 0 & 0 & 1 & 1 & 4 & 16 & 7.65 & 2.10 & 1.85 & 1 & 7 \\
\hline LLNL -TFD-SE-4 & 206 & 1 & 0 & 0 & 0 & 0 & 0 & 1 & 1 & 3 & 2 & 7.07 & 2.15 & 1.85 & 1 & 1 \\
\hline LLNL -TFD-5 & 207 & 1 & 0 & 0 & 0 & 0 & 0 & 1 & 1 & 3 & 2 & 5.43 & 2.32 & 1.78 & 1 & 1 \\
\hline LLNL -TFD-SE-5 & 208 & 1 & 0 & 0 & 0 & 0 & 0 & 1 & 1 & 3 & 2 & 9.59 & 2.24 & 1.85 & 1 & \\
\hline LLNL -TFD-S-5 & 209 & 1 & 0 & 0 & 0 & 0 & 0 & 1 & 1 & 3 & 2 & 6.65 & 2.33 & 1.85 & 1 & \\
\hline LLNL -TFE-2 & 210 & 1 & 0 & 0 & 0 & 0 & 0 & 0 & 0 & 1 & 2 & 7.83 & 2.00 & 1.78 & 1 & \\
\hline LLNL -B419-3A & 211 & 1 & 0 & 0 & 0 & 1 & 0 & 1 & 1 & 4 & 8 & 5.27 & 2.02 & 1.60 & 1 & 61 \\
\hline LLNL -TFE-SW-3B & 212 & 1 & 0 & 0 & 1 & 1 & 0 & 1 & 1 & 5 & 16 & 6.61 & 2.18 & 1.78 & 1 & 4 \\
\hline LLNL -B419-3B & 213 & 1 & 0 & 0 & 0 & 0 & 0 & 1 & 0 & 2 & 2 & 6.97 & 2.06 & 1.78 & 1 & \\
\hline LLNL -TFE-E-4 & 214 & 1 & 0 & 0 & 1 & 1 & 0 & 1 & 1 & 5 & 16 & 7.37 & 2.15 & 1.85 & 1 & 13 \\
\hline LLNL -TF518-Perched & 215 & 1 & 0 & 0 & 0 & 0 & 0 & 1 & 1 & 3 & 2 & 6.70 & 1.52 & & 1 & \\
\hline LLNL -TF5475-5 & 216 & 1 & 0 & 0 & 1 & 1 & 0 & 1 & 1 & 5 & 16 & 6.85 & 2.10 & 1.40 & 1 & 10 \\
\hline LLNL -TFC-N-1B & 217 & 1 & 0 & 0 & 1 & 0 & 0 & 1 & 0 & 3 & 16 & 6.00 & 1.95 & 1.85 & 1 & \\
\hline LLNL -TFG-S-1B & 218 & 1 & 0 & 0 & 1 & 1 & 0 & 1 & 0 & 4 & 16 & 6.30 & 2.02 & 1.78 & 1 & \\
\hline LLNL -TFD-ETC-S-2 & 219 & 1 & 0 & 0 & 0 & 0 & 0 & 1 & 1 & 3 & 2 & 7.00 & 2.00 & 1.85 & 1 & \\
\hline
\end{tabular}




\begin{tabular}{|c|c|c|c|c|c|c|c|c|c|c|c|c|c|c|c|c|}
\hline $\begin{array}{l}\text { LLNL Site } 300 \text { - CGSA } \\
\text { Building } 875 \\
\end{array}$ & 59 & 1 & 0 & 0 & 0 & 0 & 0 & 0 & 0 & 1 & 2 & 7.30 & 1.30 & 3.00 & 1 & \\
\hline $\begin{array}{l}\text { LLNL Site } 300 \text { - B834 Core } \\
\text { Area }\end{array}$ & 60 & 1 & 0 & 0 & 0 & 0 & 0 & 0 & 1 & 2 & 2 & 7.00 & 1.30 & 2.57 & 1 & \\
\hline LLNL Site 300 - Pit 6 Landfill & 61 & 1 & 0 & 1 & 0 & 1 & 0 & 0 & 1 & 4 & 8 & 7.18 & 1.40 & 3.00 & 1 & \\
\hline LLNL Site 300 - HEPA B815 & 62 & 1 & 0 & 0 & 0 & 0 & 0 & 0 & 1 & 2 & 2 & 6.83 & 1.40 & 2.00 & 1 & \\
\hline LLNL Site 300 - Pits 3\&5 & 63 & 1 & 0 & 1 & 0 & 1 & 1 & 0 & 1 & 5 & 16 & 6.60 & 1.00 & 2.27 & 1 & \\
\hline LLNL Site 300 - B850 & 64 & 0 & 0 & 0 & 0 & 1 & 1 & 0 & 1 & 3 & 16 & 10.00 & 1.18 & 2.57 & 1 & \\
\hline LLNL Site 300 - B854 & 65 & 1 & 0 & 1 & 0 & 0 & 0 & 0 & 1 & 3 & 4 & 10.00 & 1.30 & 2.57 & 1 & \\
\hline LLNL Site 300 - B832 & 66 & 1 & 0 & 1 & 0 & 0 & 0 & 0 & 1 & 3 & 4 & 10.00 & 0.78 & 2.57 & 1 & \\
\hline LLNL Site 300 - B801/Pit 8 & 67 & 1 & 0 & 0 & 0 & 0 & 0 & 0 & 0 & 1 & 2 & 7.77 & 1.70 & 2.57 & 1 & \\
\hline LLNL Site 300 - B833 & 68 & 1 & 0 & 0 & 0 & 0 & 0 & 0 & 0 & 1 & 2 & & 1.34 & 2.57 & 1 & \\
\hline LLNL Site 300 - B851 & 69 & 0 & 0 & 0 & 0 & 0 & 1 & 0 & 0 & 1 & 16 & & 2.00 & 2.57 & 1 & \\
\hline $\begin{array}{l}\text { LLNL Site } 300 \text { - HEPA HE } \\
\text { Lagoons }\end{array}$ & 70 & 0 & 0 & 1 & 0 & 0 & 0 & 0 & 1 & 2 & 4 & 9.41 & 1.40 & 2.00 & 1 & \\
\hline $\begin{array}{l}\text { LLNL Site } 300 \text { - CGSA } \\
\text { Northern Plume }\end{array}$ & 220 & 1 & 0 & 0 & 0 & 0 & 0 & 0 & 0 & 1 & 2 & 8.76 & 1.30 & 3.00 & 1 & \\
\hline $\begin{array}{l}\text { LLNL Site } 300 \text { - EGSA Debris } \\
\text { Burial Trenches }\end{array}$ & 221 & 1 & 0 & 0 & 0 & 0 & 0 & 0 & 0 & 1 & 2 & 6.70 & 1.18 & 3.08 & 1 & \\
\hline $\begin{array}{l}\text { LLNL Site } 300 \text { - HEPA Burn } \\
\text { Pit }\end{array}$ & 222 & 1 & 0 & 1 & 0 & 0 & 0 & 0 & 1 & 3 & 4 & 7.70 & 1.95 & 2.00 & 1 & \\
\hline LLNL Site 300 - Pit 1 Landfill & 223 & 0 & 0 & 1 & 0 & 0 & 0 & 0 & 1 & 2 & 4 & 7.78 & 1.70 & 2.57 & 1 & \\
\hline LLNL Site 300 - Pit 2 Landfill & 224 & 0 & 0 & 0 & 0 & 0 & 0 & 0 & 1 & 1 & 1 & 6.70 & 1.70 & 2.57 & 1 & \\
\hline LLNL Site $300-B 830$ & 225 & 1 & 0 & 1 & 0 & 0 & 0 & 0 & 1 & 3 & 4 & 8.28 & 0.78 & 2.57 & 1 & \\
\hline $\begin{array}{l}\text { Los Alamos National } \\
\text { Laboratory (TA-16 - Deep } \\
\text { Groundwater Only) }\end{array}$ & 40 & 0 & 0 & 1 & 1 & 1 & 1 & 0 & 1 & 5 & 16 & & 2.88 & 2.39 & 1 & \\
\hline Maybell & 146 & 0 & 0 & 0 & 1 & 0 & 1 & 0 & 1 & 3 & 16 & & 2.00 & & 1 & \\
\hline Mexican Hat & 147 & 0 & 0 & 0 & 1 & 0 & 1 & 1 & 1 & 4 & 16 & & & & 1 & \\
\hline Miam isburg Project - OU 1 & 71 & 1 & 0 & 0 & 0 & 1 & 0 & 0 & 0 & 2 & 8 & 9.81 & 1.40 & 2.18 & 2 & \\
\hline $\begin{array}{l}\text { Miam isburg Project - Well } \\
411 \text { Area }\end{array}$ & 139 & 1 & 0 & 0 & 0 & 1 & 0 & 0 & 0 & 2 & 8 & & 1.40 & & 2 & \\
\hline Miam isburg Project - Tritium & 150 & 1 & 0 & 0 & 0 & 1 & 1 & 0 & 0 & 3 & 16 & & 1.40 & & 2 & \\
\hline $\begin{array}{l}\text { Miam isburg Project - } \\
\text { Tributary Valley VOCs }\end{array}$ & 151 & 1 & 0 & 0 & 0 & 1 & 0 & 0 & 0 & 2 & 8 & & 1.40 & 2.18 & 2 & \\
\hline $\begin{array}{l}\text { Monticello Remedial Action } \\
\text { Project }\end{array}$ & 148 & 0 & 0 & 0 & 1 & 0 & 1 & 0 & 0 & 2 & 16 & & 1.70 & & 1 & \\
\hline Monument Valley & 149 & 0 & 0 & 0 & 0 & 0 & 0 & 1 & 1 & 2 & 1 & & 1.90 & 2.08 & 1 & \\
\hline Naturita & 152 & 0 & 0 & 0 & 1 & 0 & 1 & 0 & 0 & 2 & 16 & & 2.00 & 1.30 & 1 & \\
\hline New Rifle & 72 & 0 & 0 & 0 & 1 & 0 & 1 & 0 & 1 & 3 & 16 & & 2.90 & & 1 & \\
\hline NTS - Frenchman Flat & 73 & 0 & 0 & 0 & 0 & 1 & 1 & 0 & 0 & 2 & 16 & & 3.30 & & 1 & \\
\hline NTS - West Pahute Mesa & 74 & 0 & 0 & 0 & 0 & 1 & 1 & 0 & 0 & 2 & 16 & & 3.20 & & 1 & \\
\hline NTS - Yucca Flat & 75 & 0 & 0 & 0 & 0 & 1 & 1 & 0 & 0 & 2 & 16 & & 3.30 & & 1 & \\
\hline NTS - Central Pahute Mesa & 76 & 0 & 0 & 0 & 0 & 1 & 1 & 0 & 0 & 2 & 16 & & 3.20 & & 1 & \\
\hline NTS - Climax Mine & 77 & 0 & 0 & 0 & 0 & 1 & 1 & 0 & 0 & 2 & 16 & & 3.20 & & 1 & \\
\hline $\begin{array}{l}\text { NTS - Rainer } \\
\text { Mesa/Shoshone Mesa }\end{array}$ & 153 & 0 & 0 & 0 & 0 & 1 & 1 & 0 & 0 & 2 & 16 & & 1.48 & 1.48 & 1 & \\
\hline ORNL - Central & 78 & 1 & 0 & 0 & 1 & 1 & 1 & 0 & 0 & 4 & 16 & 7.85 & 2.00 & 3.00 & 2 & \\
\hline ORNL East & 79 & 1 & 1 & 0 & 0 & 0 & 0 & 0 & 0 & 2 & 2 & 7.84 & & & 2 & \\
\hline ORNL West & 80 & 0 & 0 & 0 & 0 & 1 & 1 & 0 & 0 & 2 & 16 & 8.90 & 2.00 & & 2 & \\
\hline ORNL - Melton Valley & 81 & 1 & 0 & 0 & 0 & 1 & 1 & 0 & 0 & 3 & 16 & 7.35 & 2.00 & 3.00 & 2 & 30 \\
\hline ORNL - Y-12 & 82 & 1 & 1 & 0 & 1 & 0 & 1 & 0 & 1 & 5 & 16 & 9.00 & 2.70 & 3.00 & 2 & \\
\hline ORNL - Bear Creek Valley & 83 & 1 & 0 & 0 & 0 & 0 & 1 & 0 & 1 & 3 & 16 & 9.00 & 2.00 & 3.00 & 2 & \\
\hline ORNL - ETTP Main Plant & 84 & 1 & 1 & 0 & 0 & 0 & 1 & 0 & 0 & 3 & 16 & 7.80 & 1.30 & 2.00 & 2 & \\
\hline ORNL - ETTP K-27 & 85 & 1 & 0 & 0 & 0 & 1 & 1 & 0 & 0 & 3 & 16 & 4.70 & 1.48 & 0.00 & 2 & \\
\hline ORNL - ETTP 1070-A & 86 & 1 & 0 & 0 & 0 & 0 & 0 & 0 & 0 & 1 & 2 & 7.15 & 1.48 & 2.00 & 2 & \\
\hline Old Rifle & 154 & 0 & 0 & 0 & 1 & 0 & 1 & 0 & 1 & 3 & 16 & & 1.48 & 1.48 & 1 & \\
\hline $\begin{array}{l}\text { Paducah Plant - GW OU (NW } \\
\text { Plume) }\end{array}$ & 155 & 1 & 0 & 0 & 0 & 0 & 1 & 0 & 0 & 2 & 16 & 5.86 & 2.00 & 2.56 & 2 & \\
\hline $\begin{array}{l}\text { Paducah Plant - GW OU (NE } \\
\text { Plume) }\end{array}$ & 156 & 1 & 0 & 0 & 0 & 0 & 1 & 0 & 0 & 2 & 16 & 8.46 & 2.00 & 2.56 & 2 & \\
\hline $\begin{array}{l}\text { Paducah Plant - GW OU (SW } \\
\text { Plume) }\end{array}$ & 157 & 1 & 0 & 0 & 0 & 0 & 1 & 0 & 0 & 2 & 16 & 8.41 & 2.00 & 2.56 & 2 & \\
\hline $\begin{array}{l}\text { Pantex Plant - Northeast On- } \\
\text { site Perched Aquifer }\end{array}$ & 87 & 1 & 0 & 1 & 1 & 0 & 0 & 0 & 0 & 3 & 16 & 8.70 & 2.43 & 2.00 & 1 & \\
\hline $\begin{array}{l}\text { Pantex Plant - Southeast On- } \\
\text { site Perched Aquifer }\end{array}$ & 88 & 1 & 0 & 1 & 1 & 0 & 0 & 0 & 0 & 3 & 16 & 7.66 & 2.42 & 2.00 & 1 & \\
\hline \begin{tabular}{|l} 
Pantex Plant - On-site \\
Ogallala Aquifer
\end{tabular} & 89 & 1 & 0 & 0 & 0 & 0 & 0 & 0 & 0 & 1 & 2 & & 2.60 & 2.40 & 1 & \\
\hline
\end{tabular}




\begin{tabular}{|c|c|c|c|c|c|c|c|c|c|c|c|c|c|c|c|c|}
\hline Pinellas Plant (1) & 158 & 1 & 0 & 0 & 0 & 0 & 0 & 0 & 0 & 1 & 2 & & & & 2 & \\
\hline Pinellas Plant (2) & 159 & 0 & 0 & 0 & 0 & 0 & 0 & 0 & 1 & 0 & & & & & 2 & \\
\hline Pinellas Plant (3) & 160 & 1 & 0 & 0 & 0 & 0 & 0 & 0 & 0 & 1 & 2 & & & & 2 & \\
\hline $\begin{array}{l}\text { Portsmouth Plant - } 5 \text { Unit } \\
\text { Plume }\end{array}$ & 91 & 1 & 0 & 0 & 0 & 0 & 0 & 0 & 0 & 1 & 2 & & 1.00 & 1.56 & 2 & \\
\hline Portsmouth Plant - X-749 & 92 & 1 & 0 & 0 & 0 & 0 & 1 & 0 & 0 & 2 & 16 & & 1.00 & 1.86 & 2 & \\
\hline Portsmouth Plant - X-740 & 93 & 1 & 0 & 0 & 0 & 0 & 0 & 0 & 0 & 1 & 2 & & 1.00 & & 2 & \\
\hline Portsmouth Plant - X701B & 94 & 1 & 0 & 0 & 0 & 0 & 1 & 0 & 0 & 2 & 16 & & 1.00 & 1.86 & 2 & \\
\hline $\begin{array}{l}\text { Portsmouth Plant - } 7 \text { Unit } \\
\text { Plume }\end{array}$ & 95 & 1 & 0 & 0 & 0 & 0 & 1 & 0 & 0 & 2 & 16 & & 1.00 & 2.82 & 2 & \\
\hline Portsmouth Plant - X-120 & 96 & 1 & 0 & 0 & 0 & 0 & 0 & 0 & 0 & 1 & 2 & & 1.00 & 1.56 & 2 & \\
\hline Project Shoal & 97 & 0 & 0 & 0 & 1 & 1 & 1 & 0 & 0 & 3 & 16 & & 3.08 & 2.00 & 1 & \\
\hline Rio Blanco & 102 & 0 & 0 & 0 & 1 & 1 & 1 & 0 & 0 & 3 & 16 & & 3.77 & 1.00 & 1 & \\
\hline Riverton & 164 & 0 & 0 & 0 & 1 & 0 & 1 & 1 & 0 & 3 & 16 & & 2.00 & 2.48 & 1 & \\
\hline Rocky Flats - Mound Plume & 98 & 1 & 0 & 0 & 0 & 0 & 1 & 0 & 0 & 2 & 16 & 9.08 & 1.00 & 1.48 & 1 & \\
\hline Rocky Flats - East Trenches & 99 & 1 & 0 & 0 & 0 & 0 & 0 & 0 & 0 & 1 & 2 & 8.46 & 1.00 & 1.48 & 1 & \\
\hline Rocky Flats - Solar Ponds & 100 & 0 & 0 & 0 & 0 & 0 & 1 & 0 & 1 & 2 & 16 & 7.55 & & 1.48 & 1 & \\
\hline Rocky Flats - 903 Pad & 101 & 1 & 0 & 0 & 0 & 0 & 0 & 0 & 0 & 1 & 2 & 7.60 & & 1.48 & 1 & \\
\hline $\begin{array}{l}\text { Rocky Flats - } 881 \text { Hillside } \\
\text { Drum Storage Area }\end{array}$ & 161 & 1 & 0 & 0 & 0 & 0 & 0 & 0 & 0 & 1 & 2 & & & & 1 & \\
\hline $\begin{array}{l}\text { Rocky Flats - Carbon } \\
\text { Tetrachoride Spill } \\
\end{array}$ & 162 & 1 & 0 & 0 & 0 & 0 & 0 & 0 & 0 & 1 & 2 & & & & 1 & \\
\hline Rocky Flats - Industrial Area & 163 & 1 & 0 & 0 & 0 & 0 & 0 & 0 & 0 & 1 & 2 & & & & 1 & \\
\hline Rocky Flats - Rulison & 103 & 0 & 0 & 0 & 1 & 1 & 1 & 0 & 0 & 3 & 16 & & 3.93 & 1.00 & 1 & \\
\hline Rocky Flats - Alluvial & 104 & 0 & 0 & 0 & 1 & 1 & 0 & 0 & 0 & 2 & 16 & & 1.60 & 0.48 & 1 & \\
\hline Rocky Flats - Salt Lake City & 165 & 0 & 0 & 0 & 1 & 0 & 1 & 0 & 0 & 2 & 16 & & 1.70 & 2.23 & 1 & \\
\hline Rocky Flats - Fuel Oil Spill & 169 & 0 & 1 & 0 & 0 & 0 & 0 & 0 & 0 & 1 & 2 & & 2.70 & & 1 & \\
\hline Rocky Flats - Navy Landfill & 188 & 1 & 0 & 0 & 0 & 0 & 0 & 0 & 0 & 1 & 2 & & 3.70 & 0.00 & 1 & 1 \\
\hline $\begin{array}{l}\text { Rocky Flats - Chemical } \\
\text { Waste Landfill (ChWLF) }\end{array}$ & 105 & 1 & 0 & 0 & 0 & 0 & 0 & 0 & 0 & 1 & 2 & & 2.70 & & 1 & \\
\hline Rocky Flats - Tijeras Arroyo & 106 & 1 & 0 & 0 & 0 & 0 & 0 & 0 & 0 & 1 & 2 & & 2.51 & & 1 & \\
\hline Rocky Flats - TA5 & 107 & 1 & 0 & 0 & 0 & 0 & 0 & 0 & 0 & 1 & 2 & & 2.70 & & 1 & \\
\hline Rocky Flats - Canyons & 187 & 0 & 1 & 0 & 0 & 0 & 0 & 0 & 1 & 2 & 2 & & 2.51 & 0.00 & 1 & \\
\hline $\begin{array}{l}\text { SRS - A-Area Burning/Rubble } \\
\text { Pits }\end{array}$ & 109 & 1 & 0 & 0 & 0 & 0 & 0 & 0 & 0 & 1 & 2 & 6.90 & 2.11 & 2.48 & 2 & \\
\hline SRS - A/M Area Groundwater & 110 & 1 & 0 & 0 & 1 & 0 & 0 & 0 & 0 & 2 & 16 & 7.59 & 2.60 & 2.79 & 2 & \\
\hline $\begin{array}{l}\text { SRS - C Area Burning/Rubble } \\
\text { Pits }\end{array}$ & 111 & 1 & 0 & 0 & 0 & 0 & 0 & 0 & 0 & 1 & 2 & & 1.78 & 3.78 & 2 & \\
\hline $\begin{array}{l}\text { SRS - C-Area Groundwater } \\
\text { Operable Unit }\end{array}$ & 112 & 1 & 0 & 0 & 0 & 1 & 0 & 0 & 0 & 2 & 8 & & 1.85 & 3.78 & 2 & \\
\hline SRS - CMP Pits & 113 & 1 & 0 & 0 & 0 & 0 & 0 & 0 & 0 & 1 & 2 & & 1.85 & 2.00 & 2 & 810 \\
\hline SRS - D-Area Groundwater & 114 & 1 & 0 & 0 & 1 & 1 & 1 & 1 & 1 & 6 & 16 & & 0.70 & 2.70 & 2 & \\
\hline $\begin{array}{l}\text { SRS - D-Area Oil Seepage } \\
\text { Basin }\end{array}$ & 115 & 1 & 1 & 0 & 0 & 0 & 0 & 0 & 0 & 2 & 2 & & 1.60 & 1.78 & 2 & \\
\hline $\begin{array}{l}\text { SRS - F Area Seepage } \\
\text { Basins }\end{array}$ & 116 & 0 & 0 & 0 & 1 & 1 & 1 & 0 & 1 & 4 & 16 & & 0.00 & 3.56 & 2 & \\
\hline $\begin{array}{l}\text { SRS - H Area Seepage } \\
\text { Basins }\end{array}$ & 117 & 1 & 0 & 0 & 1 & 1 & 1 & 0 & 1 & 5 & 16 & & 0.00 & 3.56 & 2 & \\
\hline SRS - Central Shops GW OU & 118 & 1 & 0 & 0 & 0 & 0 & 0 & 0 & 0 & 1 & 2 & & 1.78 & & 2 & \\
\hline $\begin{array}{l}\text { SRS - K Area Burning/Rubble } \\
\text { Pit }\end{array}$ & 119 & 1 & 0 & 0 & 0 & 0 & 0 & 0 & 0 & 1 & 2 & & 1.70 & 1.70 & 2 & \\
\hline $\begin{array}{l}\text { SRS - K Area Goundwater } \\
\text { Operable Unit }\end{array}$ & 120 & 1 & 0 & 0 & 0 & 1 & 0 & 0 & 0 & 2 & 8 & & 1.70 & 1.70 & 2 & \\
\hline $\begin{array}{l}\text { SRS - L Area Burning/Rubble } \\
\text { Pit }\end{array}$ & 121 & 1 & 0 & 0 & 0 & 0 & 0 & 0 & 0 & 1 & 2 & & 1.54 & 1.70 & 2 & 13 \\
\hline $\begin{array}{l}\text { SRS - L Area Southern } \\
\text { Groundwater }\end{array}$ & 122 & 1 & 0 & 0 & 0 & 1 & 0 & 0 & 0 & 2 & 8 & & 1.78 & 2.18 & 2 & 14 \\
\hline $\begin{array}{l}\text { SRS - Miscellaneous } \\
\text { Chemical Basin }\end{array}$ & 123 & 1 & 0 & 0 & 0 & 0 & 0 & 0 & 0 & 1 & 2 & & 2.35 & 2.79 & 2 & \\
\hline $\begin{array}{l}\text { SRS - Mixed Waste } \\
\text { Management Facility } \\
\text { Northeast Plume }\end{array}$ & 124 & 1 & 0 & 0 & 0 & 1 & 0 & 0 & 0 & 2 & 8 & & 1.78 & 3.56 & 2 & \\
\hline $\begin{array}{l}\text { SRS - Mixed Waste } \\
\text { Management Facility } \\
\text { Northwest Plume }\end{array}$ & 125 & 1 & 0 & 0 & 0 & 1 & 0 & 0 & 0 & 2 & 8 & & 1.78 & 3.56 & 2 & \\
\hline $\begin{array}{l}\text { SRS - Mixed Waste } \\
\text { Management Facility } \\
\text { Southeast Plume }\end{array}$ & 126 & 1 & 0 & 0 & 0 & 1 & 1 & 0 & 0 & 3 & 16 & & 1.78 & 3.56 & 2 & \\
\hline
\end{tabular}




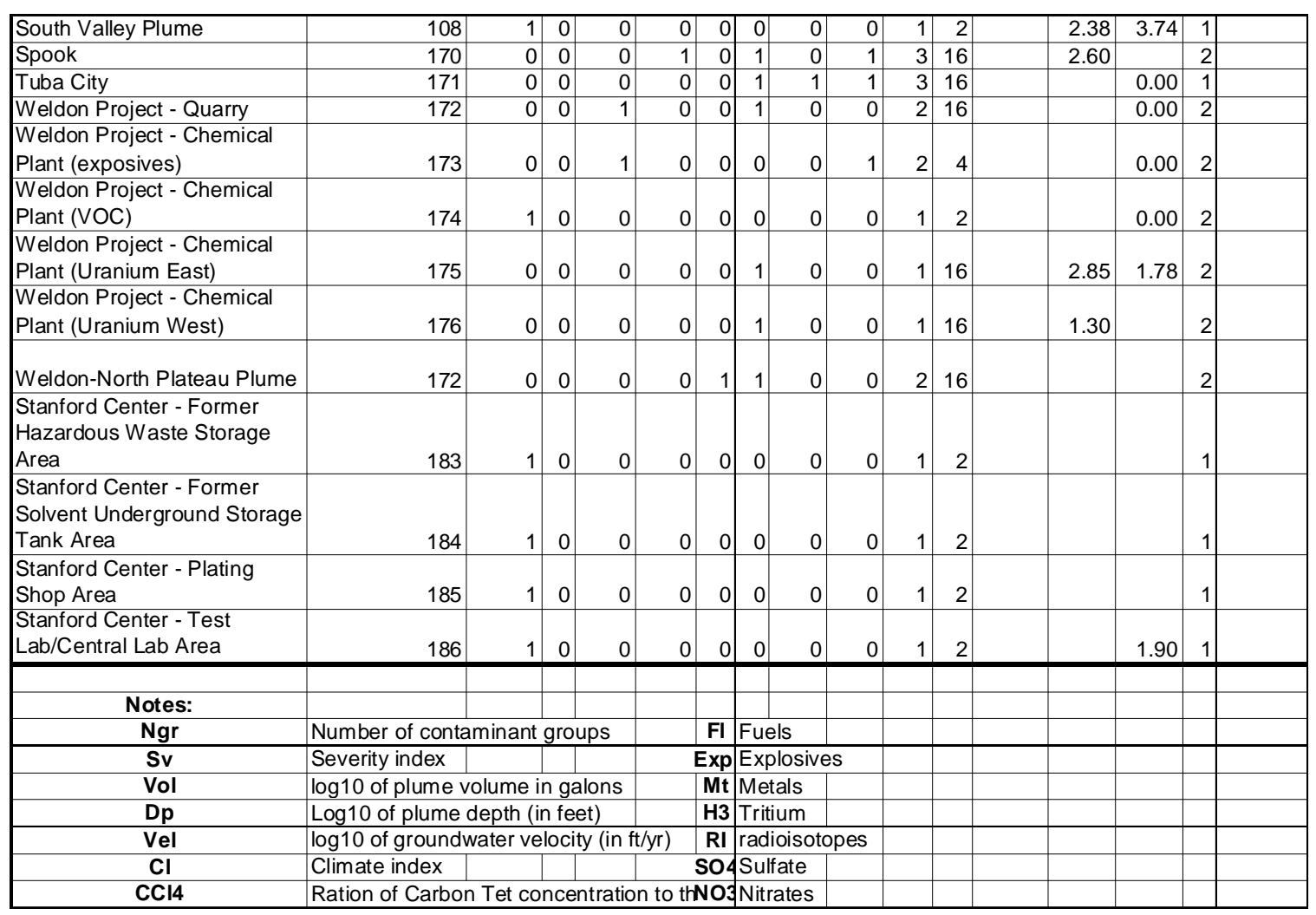


Table S2. Frequency of occurrence of contaminant groups in groundwater plumes (total number of plumes in the GWD is 221). The contaminant groups are sorted according to the frequency of their occurrence.

\begin{tabular}{|l|c|c|}
\hline Contaminant Groups & $\begin{array}{c}\text { Plumes } \\
\text { surveyed for } \\
\text { specific } \\
\text { contaminant } \\
\text { groups }\end{array}$ & $\begin{array}{c}\text { Number and \% of } \\
\text { plumes with specific } \\
\text { contaminant groups }\end{array}$ \\
\hline CVOCs & 175 & $147(84 \%)$ \\
\hline Tritium & 164 & $84(51 \%)$ \\
\hline Isotopes & 196 & $92(47 \%)$ \\
\hline Nitrates & 155 & $71(46 \%)$ \\
\hline Metals & 177 & $76(43 \%)$ \\
\hline Sulfate & 139 & $44(32 \%)$ \\
\hline Fuel & 146 & $16(11 \%)$ \\
\hline Explosives & 146 & $15(10 \%)$ \\
\hline
\end{tabular}


Table S3. Ranking of plumes with binary association of contaminant groups (given as a percent of plumes identified for both groups). Mixed wastes are in bold.

\begin{tabular}{|c|c|c|}
\hline Percent & \multicolumn{2}{|c|}{ Contaminant groups } \\
\hline $35 \%$ & CVOCs & Tritium \\
\hline $31 \%$ & Tritium & Isotopes \\
\hline $30 \%$ & CVOCs & Nitrate \\
\hline $28 \%$ & Metals & Isotopes \\
\hline $26 \%$ & VOCs & Sulfate \\
\hline $24 \%$ & CVoCs & Isotopes \\
\hline $24 \%$ & Metals & Nitrate \\
\hline $24 \%$ & CVOCs & Metals \\
\hline $23 \%$ & Isotopes & Nitrate \\
\hline $23 \%$ & Metals & Tritium \\
\hline $22 \%$ & Sulfate & Nitrate \\
\hline $19 \%$ & Tritium & Nitrate \\
\hline $17 \%$ & Metals & Sulfate \\
\hline $10 \%$ & Tritium & Sulfate \\
\hline $7 \%$ & Explosives & Nitrate \\
\hline $7 \%$ & CVOCs & Fuel \\
\hline $6 \%$ & CVOCs & Explosives \\
\hline $5 \%$ & Isotopes & sulfate \\
\hline $3 \%$ & Fuel & Isotopes \\
\hline $3 \%$ & Explosives & Metals \\
\hline $3 \%$ & Fuel & Metals \\
\hline $3 \%$ & Explosives & tritium \\
\hline $2 \%$ & Fuel & Nitrate \\
\hline $2 \%$ & Fuel & Tritium \\
\hline $2 \%$ & Explosives & Isotopes \\
\hline $1 \%$ & Fuel & Sulfate \\
\hline $0 \%$ & Fuel & Explosives \\
\hline $0 x \%$ & Explosives & Sulfate \\
\hline
\end{tabular}


Table S4. Ternary, quaternary, and quinary combinations of contaminant groups in groundwater plumes. The most frequent contaminant groups are shown in bold.

\begin{tabular}{|c|c|c|c|c|c|c|c|c|c|}
\hline & CVOCs & Fuels & Explosives & Metals & Tritium & Isotopes & Sulfates & Nitrates & $\begin{array}{l}\text { Number of } \\
\text { contaminant } \\
\text { groups }\end{array}$ \\
\hline \multicolumn{10}{|c|}{ (a) Ternary } \\
\hline $\begin{array}{l}\text { Number } \\
\text { of plumes }\end{array}$ & 403 & & 7 & 30 & 29 & 37 & 18 & 28 & 192 \\
\hline $\begin{array}{c}\text { Frequency } \\
(\% \%)\end{array}$ & 20.8 & 1.63. & 6 & 15.6 & 15.1 & 19.3 & 9.414 & .6 & 100 \\
\hline \multicolumn{10}{|c|}{ (b) Quaternary } \\
\hline $\begin{array}{l}\text { Number } \\
\text { of plumes }\end{array}$ & 180 & & 1 & 19 & 17 & 15 & 12 & 22 & 104 \\
\hline $\begin{array}{c}\text { Frequency } \\
(\% \%)\end{array}$ & 17.3 & 0.01 . & 0 & 18.3 & 16.3 & 14.411 & .5 & 21.2 & 100 \\
\hline \multicolumn{10}{|c|}{ (c) Quinary } \\
\hline $\begin{array}{l}\text { Number } \\
\text { of plumes }\end{array}$ & 102 & & 2 & 10 & 9 & 7 & 5 & 10 & 55 \\
\hline $\begin{array}{c}\text { Frequency } \\
(\% \%)\end{array}$ & 18.2 & 3.63 . & 6 & 18.2 & 16.4 & 12.79 . & 1 & 18.2 & 100 \\
\hline
\end{tabular}


Table S5. Occurrence of individual contaminants in contaminated groups

(a) Chlorinated hydrocarbons (number of plumes is 147)

\begin{tabular}{|c|c|c|c|c|c|c|c|c|c|c|c|c|c|c|}
\hline VOCs & 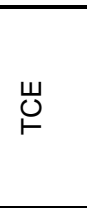 & $\begin{array}{l}\stackrel{U}{0} \\
\square\end{array}$ & 岂 & Ł & s & $\begin{array}{l}\mathbb{\delta} \\
\square\end{array}$ & 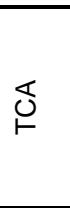 & 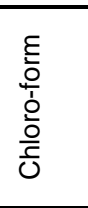 & 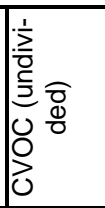 & $\begin{array}{l}\text { 总 } \\
\frac{\mathscr{d}}{\tilde{L}}\end{array}$ & $\begin{array}{l}\frac{\mathbb{O}}{\frac{0}{0}} \\
\frac{0}{0}\end{array}$ & 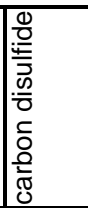 & 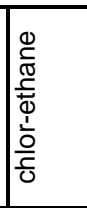 & 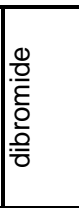 \\
\hline $\begin{array}{l}\text { Number of } \\
\text { plumes with } \\
\text { a specific } \\
\text { compound }\end{array}$ & 127 & 70 & 36 & 35 & 18 & 12 & 10 & 8 & 7 & 6 & 2 & 1 & 1 & 1 \\
\hline $\begin{array}{l}\text { Frequency of } \\
\text { occurrence } \\
\text { among other } \\
\text { CVOCs } \\
\text { compounds } \\
\text { (\%) }\end{array}$ & 38.0 & 21.0 & 10.8 & 10.5 & 5.4 & 3.6 & 3.0 & 2.4 & 2.1 & 1.8 & 0.6 & 0.3 & 0.3 & 0.3 \\
\hline $\begin{array}{l}\text { Frequency of } \\
\text { occurrence in } \\
\text { CVOCs } \\
\text { contaminated } \\
\text { plumes (\%) }\end{array}$ & 86.4 & 47.6 & 24.5 & 23.8 & 12.2 & 8.2 & 6.8 & 5.4 & 4.8 & $4.1 \%$ & 1.4 & 0.7 & 0.7 & 0.7 \\
\hline $\begin{array}{l}\text { Frequency of } \\
\text { occurrence in } \\
\text { all plumes } \\
(\%)\end{array}$ & 57.5 & 31.7 & 16.3 & 15.8 & 8.1 & 5.4 & 4.5 & 3.6 & 3.2 & 2.7 & 0.9 & 0.5 & 0.5 & 0.5 \\
\hline
\end{tabular}


(b) Fuel or fuel components (number of plumes is 16)

\begin{tabular}{|c|c|c|c|c|c|c|c|c|c|c|}
\hline Fuel & 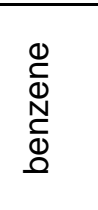 & $\begin{array}{l}\bar{\Phi} \\
\mathscr{\mathscr { N }} \\
. \frac{0}{0}\end{array}$ & 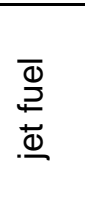 & 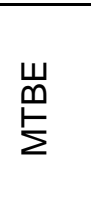 & $\frac{\stackrel{0}{\frac{D}{d}}}{\frac{0}{0}}$ & 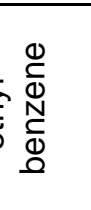 & $=$ & శ & 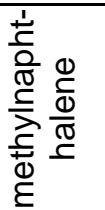 & other \\
\hline $\begin{array}{l}\text { Number of plumes } \\
\text { with a specific fuel } \\
\text { compound }\end{array}$ & 7 & 7 & 2 & 2 & 2 & 1 & 1 & 1 & 1 & 1 \\
\hline $\begin{array}{l}\text { Frequency of } \\
\text { occurrence among } \\
\text { other fuel } \\
\text { compounds (\%) }\end{array}$ & 29.2 & 29.2 & 8.3 & 8.3 & 8.3 & 4.2 & 4.2 & 4.2 & 4.2 & 4.2 \\
\hline $\begin{array}{l}\text { Frequency of } \\
\text { occurrence in fuel } \\
\text { contaminated } \\
\text { plumes (\%) }\end{array}$ & 43.8 & 43.8 & 12.5 & 12.5 & 12.5 & 6.3 & 6.3 & 6.3 & 6.3 & 6.3 \\
\hline $\begin{array}{l}\text { Frequency of } \\
\text { occurrence in all } \\
\text { plumes (\%) }\end{array}$ & 3.2 & 3.2 & 0.9 & 0.9 & 0.9 & 0.5 & 0.5 & 0.5 & 0.5 & 0.5 \\
\hline
\end{tabular}


(c) Explosives (number of plumes is 15)

\begin{tabular}{|c|c|c|c|c|c|c|c|}
\hline Explosives & $\begin{array}{l}\frac{0}{\pi} \\
\frac{0}{0} \\
\frac{0}{0} \\
\frac{1}{0} \\
0\end{array}$ & 乬 & $\sum_{I}^{X}$ & 솜 & $\sum_{1}^{\varrho}$ & $\stackrel{上}{⺊}$ & 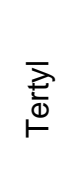 \\
\hline $\begin{array}{l}\text { Number of plumes } \\
\text { with a specific } \\
\text { explosive compound }\end{array}$ & 9 & 5 & 5 & 4 & 4 & 3 & 1 \\
\hline $\begin{array}{l}\text { Frequency of } \\
\text { occurrence among } \\
\text { other explosive } \\
\text { compounds (\%) }\end{array}$ & 29.0 & 16.1 & 16.1 & 12.9 & 12.9 & 9.7 & 3.2 \\
\hline $\begin{array}{l}\text { Frequency of } \\
\text { occurrence in } \\
\text { explosive } \\
\text { contaminated plumes } \\
\text { (\%) }\end{array}$ & 60.0 & 33.3 & 33.3 & 26.7 & 26.7 & 20.0 & 6.7 \\
\hline $\begin{array}{l}\text { Frequency of } \\
\text { occurrence in all } \\
\text { plumes (\%) }\end{array}$ & 4.1 & 2.3 & 2.3 & 1.8 & 1.8 & 1.4 & 0.5 \\
\hline
\end{tabular}


(d) Metals (number of plumes is 70)

\begin{tabular}{|c|c|c|c|c|c|c|c|c|c|c|c|}
\hline METALS & $\bar{U}$ & $\stackrel{\circ}{\Sigma}$ & 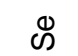 & 里 & $\frac{0}{2}$ & 옴 & $\stackrel{5}{\Sigma}$ & ర্ & $\bar{z}$ & $\ddot{\infty}$ & $>$ \\
\hline $\begin{array}{l}\text { Number of } \\
\text { plumes with } \\
\text { specific } \\
\text { metals }\end{array}$ & 42 & 16 & 13 & 9 & 7 & 6 & 6 & 5 & 4 & 3 & 3 \\
\hline $\begin{array}{l}\text { Occurrence } \\
\text { with other } \\
\text { metals }\end{array}$ & 33.3 & 12.7 & 10.3 & 7.1 & 5.6 & 4.8 & 4.8 & 4.0 & 3.2 & 2.4 & 2.4 \\
\hline $\begin{array}{l}\text { Occurrence } \\
\text { in metal } \\
\text { contaminated } \\
\text { plumes }\end{array}$ & 60.0 & 22.9 & 18.6 & 12.9 & 10.0 & 8.6 & 8.6 & 7.1 & 5.7 & 4.3 & 4.3 \\
\hline $\begin{array}{l}\text { Occurrence } \\
\text { in all plumes }\end{array}$ & 19.0 & 7.2 & 5.9 & 4.1 & 3.2 & 2.7 & 2.7 & 2.3 & 1.8 & 1.4 & 1.4 \\
\hline
\end{tabular}

\begin{tabular}{|c|c|c|c|c|c|c|c|c|}
\hline METALS & ๑ి & 8 & 芒 & $\sum^{*}$ & 飞 & $\stackrel{\oplus}{\oplus}$ & $\bar{U}$ & $\tilde{N}$ \\
\hline $\begin{array}{l}\text { Number of } \\
\text { plumes with } \\
\text { specific } \\
\text { metals }\end{array}$ & 2 & 2 & 2 & 2 & 1 & 1 & 1 & 1 \\
\hline $\begin{array}{l}\text { Occurrence } \\
\text { with other } \\
\text { metals }\end{array}$ & 1.6 & 1.6 & 1.6 & 1.6 & 0.8 & 0.8 & 0.8 & 0.8 \\
\hline $\begin{array}{l}\text { Occurrence in } \\
\text { metal } \\
\text { contaminated } \\
\text { plumes }\end{array}$ & 2.9 & 2.9 & 2.9 & 2.9 & 1.4 & 1.4 & 1.4 & 1.4 \\
\hline $\begin{array}{l}\text { Occurrence in } \\
\text { all plumes }\end{array}$ & 0.9 & 0.9 & 0.9 & 0.9 & 0.5 & 0.5 & 0.5 & 0.5 \\
\hline
\end{tabular}


(e) Radioactive isotopes (number of plumes is 98)

\begin{tabular}{|c|c|c|c|c|c|c|c|c|c|c|c|c|c|c|}
\hline Radionuclides & $\supset$ & $\bar{n}$ & $\stackrel{0}{\bullet}$ & $\underline{\star}$ & $\widetilde{\pi}$ & $\stackrel{*}{F}$ & 药 & $\begin{array}{l}\text { o } \\
\frac{\pi}{0} \\
\frac{1}{2} \\
0 \\
0 \\
0 \\
0 \\
0\end{array}$ & 委 & 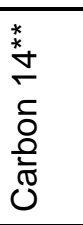 & : & $\frac{k}{2}$ & $\begin{array}{l}\frac{\pi}{2} \\
0 \\
0 \\
\text { N } \\
0 \\
0 \\
0\end{array}$ & $\mid$ \\
\hline $\begin{array}{l}\text { Number of } \\
\text { plumes }\end{array}$ & 44 & 24 & 16 & 8 & 4 & 4 & 3 & 3 & 1 & 1 & 1 & 1 & 1 & 1 \\
\hline $\begin{array}{l}\text { Occurrence } \\
\text { with other } \\
\text { radionuclides }\end{array}$ & 39.3 & 21.4 & 14.3 & 7.1 & 3.6 & 3.6 & 2.7 & 2.7 & 0.9 & 0.9 & 0.9 & 0.9 & 0.9 & 0.9 \\
\hline $\begin{array}{l}\text { Occurrence in } \\
\text { plumes with } \\
\text { radionuclides }\end{array}$ & 44.9 & 24.5 & 16.3 & 8.2 & 4.1 & 4.1 & 3.1 & 3.1 & 1.0 & 1.0 & 1.0 & 1.0 & 1.0 & 1.0 \\
\hline $\begin{array}{l}\text { Occurrence in } \\
\text { all plumes }\end{array}$ & 19.9 & 10.9 & 7.2 & 3.6 & 1.8 & 1.8 & 1.4 & 1.4 & 0.5 & 0.5 & 0.5 & 0.5 & 0.5 & 0.5 \\
\hline
\end{tabular}


Table S6. Types and ranking of plumes with binary combinations of individual contaminants. Mixed waste is in bold.

\begin{tabular}{|c|c|c|}
\hline \multicolumn{2}{|c|}{ Co-contaminants } & Percent of identified plumes \\
\hline \multicolumn{3}{|c|}{ Chlorinated Hydrocarbons - Nitrate and Sulfate } \\
\hline TCE & nitrate & $28 \%$ \\
\hline TCE & sulfate & $25 \%$ \\
\hline PCE & sulfate & $20 \%$ \\
\hline PCE & nitrate & $17 \%$ \\
\hline \multicolumn{3}{|c|}{ Chlorinated Hydrocarbons - Tritium } \\
\hline TCE & tritium & $29 \%$ \\
\hline PCE & tritium & $21 \%$ \\
\hline \multicolumn{3}{|c|}{ Chlorinated Hydrocarbons - Metals } \\
\hline TCE & $\mathrm{Cr}$ & $20 \%$ \\
\hline PCE & $\mathrm{Cr}$ & $16 \%$ \\
\hline \multicolumn{3}{|c|}{ Radioisotopes-Nitrate } \\
\hline Tritium & Nitrate & $19 \%$ \\
\hline Uranium & Nitrate & $17 \%$ \\
\hline \multicolumn{3}{|c|}{ Metals-Sulfate } \\
\hline $\mathrm{Cr}$ & Sulfate & $18 \%$ \\
\hline \multicolumn{3}{|c|}{ Sulfate-Nitrate } \\
\hline Sulfate & Nitrate & $22 \%$ \\
\hline
\end{tabular}


Table S7. Summary of statistics of plume volumes (volumes are gallons). Total number of plumes is 134.

\begin{tabular}{|l|l|}
\hline Mean & $1.15 \mathrm{E}+09$ \\
\hline Standard Error & $3.81 \mathrm{E}+08$ \\
\hline Median & $3.53 \mathrm{E}+07$ \\
\hline Mode & $1.00 \mathrm{E}+06$ \\
\hline Standard Deviation & $4.41 \mathrm{E}+09$ \\
\hline Sample Variance & $1.94 \mathrm{E}+19$ \\
\hline Kurtosis & $3.53 \mathrm{E}+01$ \\
\hline Skewness & $5.63 \mathrm{E}+00$ \\
\hline Range & $3.50 \mathrm{E}+10$ \\
\hline Minimum & $5.00 \mathrm{E}+04$ \\
\hline Maximum & $3.50 \mathrm{E}+10$ \\
\hline Confidence Level (95.0\%) & \\
\hline
\end{tabular}


Table S8. Statistics of maximum activities (pCi/L) of tritium and radioisotopes in groundwater plumes

\begin{tabular}{|c|c|c|c|c|}
\hline Statistical values & Tritium & $\mathrm{Sr}$ & Tc & $\mathbf{U}$ \\
\hline Standard Error & $1.61 E+09$ & 4997291 & 1247321 & 933.2892 \\
\hline Minimum & 15 & 8 & 25 & 1 \\
\hline $1^{\text {st }}$ quartile (Q1) & 1820 & 35.75 & 311.5 & \\
\hline Median (Q2) & 18400 & 483 & 3798.5 & 201 \\
\hline Mean & $1.62 E+09$ & 5054433 & 1298130 & \\
\hline $3^{\text {rd }}$ quartile (Q3) & 219000 & 5393.5 & 48000 & \\
\hline Maximum & $1 E+11$ & $1 \mathrm{E}+08$ & 20000000 & 12400 \\
\hline IQR & 217180 & 5357.75 & 47688.5 & \\
\hline Q1-3IQR & -649720 & -16037.5 & -142754 & \\
\hline Q1-1.5IQR & -215360 & -5322 & -47377 & \\
\hline Q3+1.5IQR & 436180 & 10751.25 & 95688.5 & \\
\hline Q3+3IQR & 870540 & 21466.75 & 191065.5 & \\
\hline Standard Deviation & $1.27 \mathrm{E}+10$ & 22348563 & 4989284 & 3365.022 \\
\hline Sample Variance & $1.61 E+20$ & $4.99 \mathrm{E}+14$ & $2.49 \mathrm{E}+13$ & 11323374 \\
\hline Kurtosis & 61.99988 & 19.99709 & 15.9669 & 12.69662 \\
\hline Skewness & 7.873997 & 4.471674 & 3.994273 & 3.548152 \\
\hline Range & $1 \mathrm{E}+11$ & 99999992 & 19999975 & 12399 \\
\hline Number of occurrences & 62 & 20 & 16 & 13 \\
\hline Confidence Level(95.0\%) & $3.23 E+09$ & 10459453 & 2658604 & 2033.462 \\
\hline
\end{tabular}


Table S9. Maximum contaminant mass estimates

(a) Chlorinated hydrocarbons

\begin{tabular}{|c|c|c|c|c|c|c|}
\hline \multirow{3}{*}{ Contaminants } & \multirow{3}{*}{ 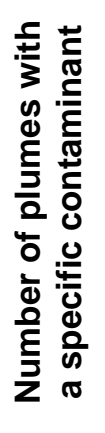 } & \multicolumn{3}{|c|}{$\begin{array}{l}\text { Plumes with known concentration } \\
\text { and volume }\end{array}$} & \multirow{2}{*}{\multicolumn{2}{|c|}{$\begin{array}{l}\text { All plumes } \\
\text { Mass (kg) }\end{array}$}} \\
\hline & & \multirow{2}{*}{ 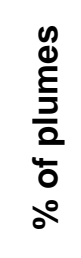 } & \multicolumn{2}{|c|}{ Mass (kg) } & & \\
\hline & & & Maximum & $\begin{array}{c}\text { Above regulatory } \\
\text { limit }\end{array}$ & Maximum & $\begin{array}{l}\text { Above regulatory } \\
\text { limit }\end{array}$ \\
\hline TCE & 127 & 74 & $1.67 \mathrm{E}+07$ & 1.67E+07 & $2.25 \mathrm{E}+07$ & $2.25 \mathrm{E}+07$ \\
\hline PCE & 70 & 81 & $6.07 \mathrm{E}+06$ & $6.07 \mathrm{E}+06$ & $7.45 \mathrm{E}+06$ & $7.45 \mathrm{E}+06$ \\
\hline CT & 35 & 86 & $1.40 \mathrm{E}+05$ & $1.40 \mathrm{E}+05$ & $1.63 \mathrm{E}+05$ & $1.63 \mathrm{E}+05$ \\
\hline DCE & 36 & 69 & 7343 & 7275 & 10574 & $1.05 E+04$ \\
\hline chloroform & 8 & 88 & 1064 & 4.5 & 1216 & 5.2 \\
\hline VC & 18 & 78 & 380.3 & 379.0 & 488.9 & 487.3 \\
\hline methylene chloride & 2 & 100 & 71.5 & 31.9 & 71.5 & 31.9 \\
\hline TCA & 10 & 50 & 126.9 & 114.3 & 253.8 & 228.5 \\
\hline DCA & 12 & 75 & 135.6 & 84.1 & 180.8 & 112.1 \\
\hline Freon* & 6 & 100 & 62.2 & & 62.2 & \\
\hline carbon disulfide & 1 & 100 & 13.5 & 0.0 & 13.5 & 0.0 \\
\hline VOC (undivided) ${ }^{\star \star}$ & 7 & 0 & & & & \\
\hline chlorethane $e^{\star \star}$ & 1 & 0 & & & & \\
\hline $\begin{array}{l}\text { ethylene } \\
\text { dibromide }^{\star *}\end{array}$ & 1 & 0 & & & & \\
\hline Total vocs & 334 & & $2.29 \mathrm{E}+07$ & $2.29 \mathrm{E}+07$ & $3.01 E+07$ & $3.01 \mathrm{E}+07$ \\
\hline
\end{tabular}


(b) Fuel and fuel components

\begin{tabular}{|c|c|c|c|c|c|c|}
\hline \multirow[t]{3}{*}{ Contaminants } & \multirow{3}{*}{ 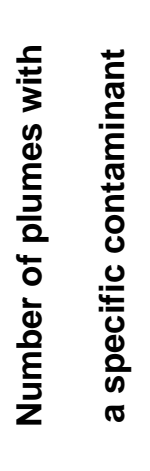 } & \multicolumn{3}{|c|}{$\begin{array}{l}\text { Plumes with known concentration and } \\
\text { volume }\end{array}$} & \multicolumn{2}{|c|}{ All plumes } \\
\hline & & g & & $(\mathrm{kg})$ & Mas & (kg) \\
\hline & & $\begin{array}{l}\frac{2}{4} \\
0 \\
0\end{array}$ & Maximum & $\begin{array}{l}\text { Above } \\
\text { regulatory } \\
\text { limit }\end{array}$ & Maximum & $\begin{array}{l}\text { Above } \\
\text { regulatory } \\
\text { limit }\end{array}$ \\
\hline Diesel* & 7 & 71 & $5.15 \mathrm{E}+06$ & & $7.21 \mathrm{E}+06$ & \\
\hline gas* $^{*}$ & 1 & 100 & 31.23 & & 31.23 & \\
\hline Benzene & 7 & 86 & 7.24 & 6.09 & 8.45 & 7.1 \\
\hline dichlorobenzene & 1 & 100 & 1.99 & 0 & 1.99 & 0 \\
\hline MTBE & 2 & 100 & 2.42 & 1.93 & 2.4 & 1.9 \\
\hline Toluene & 2 & 50 & 0.38 & 0 & 0.8 & 0 \\
\hline methylnaphthalene* & 1 & 100 & 0.17 & & 0.2 & \\
\hline ethylbenzene & 1 & 100 & 0.004 & 0 & 0.004 & 0 \\
\hline jet fuel** & 2 & 0 & & & & \\
\hline Total fuel & 24 & & 5147664 & & 7206714 & \\
\hline
\end{tabular}


(c) Explosives

\begin{tabular}{|c|c|c|c|c|c|c|}
\hline \multirow[t]{3}{*}{ Contaminants } & \multirow{3}{*}{ 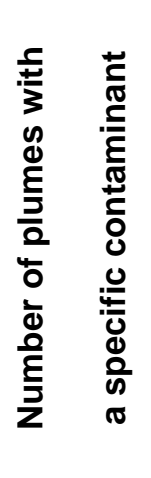 } & \multicolumn{3}{|c|}{ Plumes with known concentration and volume } & \multirow{2}{*}{\multicolumn{2}{|c|}{$\begin{array}{l}\text { All plumes } \\
\text { Mass (kg) }\end{array}$}} \\
\hline & & \multirow{2}{*}{ 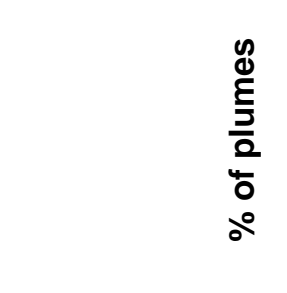 } & \multicolumn{2}{|c|}{ Mass (kg) } & & \\
\hline & & & Maximum & $\begin{array}{l}\text { Above } \\
\text { regulatory } \\
\text { limit }\end{array}$ & Maximum & $\begin{array}{l}\text { Above } \\
\text { regulatory } \\
\text { limit }\end{array}$ \\
\hline $\mathrm{RDX}^{*}$ & 4 & 75 & 20000 & & 26666.7 & \\
\hline TNB* $^{*}$ & 4 & 75 & 8500 & & 11333.3 & \\
\hline $\mathrm{HMX}^{*}$ & 5 & 80 & 4300 & & 5375 & \\
\hline DNT* & 5 & 40 & 680 & & 1700 & \\
\hline $\mathrm{TNT}^{*}$ & 3 & 67 & 1200 & & 1800 & \\
\hline perchlorate & 9 & 89 & 460 & 0 & 517.5 & 0 \\
\hline tertyl* & 1 & 100 & 2.2 & & 2.2 & \\
\hline Total & 31 & & 35142 & & 47395 & \\
\hline
\end{tabular}


(d) Metals

\begin{tabular}{|c|c|c|c|c|c|c|}
\hline \multirow{3}{*}{ Contaminants } & \multirow{3}{*}{ 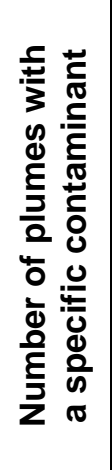 } & \multicolumn{3}{|c|}{$\begin{array}{c}\text { Plumes with known } \\
\text { concentration and volume }\end{array}$} & \multicolumn{2}{|c|}{ All plumes } \\
\hline & & \multirow{2}{*}{ 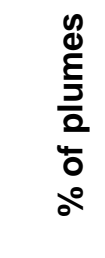 } & \multicolumn{2}{|c|}{ Mass (kg) } & \multicolumn{2}{|c|}{ Mass (kg) } \\
\hline & & & Maximum & $\begin{array}{l}\text { Above } \\
\text { regulatory } \\
\text { limit }\end{array}$ & Maximum & $\begin{array}{c}\text { Above regulatory } \\
\text { limit }\end{array}$ \\
\hline $\mathrm{Mg}^{*}$ & 2 & 100 & 647,746 & & 647,746 & \\
\hline $\mathrm{Fe}^{\dagger}$ & 2 & 100 & $1,941,214$ & $1,940,295$ & $1,941,214$ & $1,940,295$ \\
\hline $\mathrm{Mn}^{\dagger}$ & 6 & 50 & 128,574 & 121,686 & 257,148 & 243,372 \\
\hline $\mathrm{Cr}$ & 39 & 100 & 276,486 & 272,076 & 276,486 & 272,076 \\
\hline Bo & 2 & 100 & 18,054 & 0 & 18,054 & 0 \\
\hline $\mathrm{Cr}-6^{*}$ & 3 & 1300 & 276,486 & & 21,268 & \\
\hline $\mathrm{Mo}^{*}$ & 16 & 13 & 4,554 & & 36,431 & \\
\hline $\mathrm{Ba}$ & 3 & 100 & 5894 & 6.9 & 5893.9 & 6.94 \\
\hline $\mathrm{Ni}$ & 4 & 100 & 16955 & 15227.4 & 16955.1 & 15227.4 \\
\hline $\mathrm{Cu}^{\dagger}$ & 1 & 100 & 1260 & 0 & 1259.7 & 0 \\
\hline $\mathrm{Pb}$ & 7 & 71 & 1831 & 1669.4 & 2562.8 & 2337.12 \\
\hline As & 9 & 33 & 229.8 & 79.5 & 689.3 & 238.47 \\
\hline $\mathrm{Be}$ & 1 & 100 & 1068.9 & 1056.8 & 1068.9 & 1056.77 \\
\hline $\mathrm{Cd}$ & 5 & 40 & 150.7 & 116.6 & 376.6 & 291.45 \\
\hline $\mathrm{Co}^{*}$ & 2 & 100 & 131.2 & & 131.2 & \\
\hline $\mathrm{Zn}^{\dagger}$ & 1 & 100 & 67.5 & 0 & 67.5 & 0 \\
\hline $\mathrm{Hg}$ & 6 & 83 & 35.2 & 13.7 & 42.2 & 16.38 \\
\hline$A I^{\star \star}$ & 1 & 0 & & & & \\
\hline $\mathrm{Se}^{\star \star}$ & 13 & 0 & & & & \\
\hline$V^{* *}$ & 3 & 0 & & & & \\
\hline Total metals & 126 & & $3,320,735$ & & $3,227,393$ & \\
\hline
\end{tabular}


(e) Nitrates and sulfates

\begin{tabular}{|c|c|c|c|c|c|c|}
\hline \multirow[t]{3}{*}{ Contaminants } & \multirow{3}{*}{ 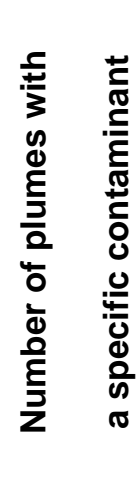 } & \multicolumn{3}{|c|}{$\begin{array}{l}\text { Plumes with known concentration and } \\
\text { volume }\end{array}$} & \multicolumn{2}{|c|}{ All plumes } \\
\hline & & o & Ma & (kg) & \multicolumn{2}{|c|}{ Mass (kg) } \\
\hline & & $\begin{array}{l}\overline{2} \\
\frac{1}{0} \\
0\end{array}$ & Maximum & $\begin{array}{l}\text { Above } \\
\text { regulatory } \\
\text { limit }\end{array}$ & Maximum & $\begin{array}{l}\text { Above } \\
\text { regulatory } \\
\text { limit }\end{array}$ \\
\hline Nitrates & 71 & 72 & $52,605,366$ & $52,603,153$ & $73,234,921$ & $73,231,840$ \\
\hline Sulfates $^{\dagger}$ & 44 & 84 & $17,926,614$ & $16,248,125$ & $21,318,136$ & $19,322,095$ \\
\hline $\begin{array}{l}\text { Total sulfates } \\
\text { and nitrates }\end{array}$ & 115 & & 70531980 & & 94553057 & \\
\hline
\end{tabular}


Table S10. Maximum activity estimates for the tritium and other radionuclides

\begin{tabular}{|c|c|c|c|c|c|c|}
\hline \multirow{3}{*}{ Contaminants } & \multirow{3}{*}{ 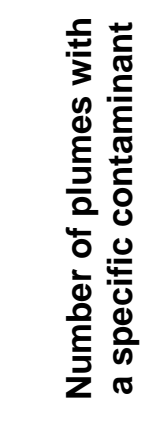 } & \multicolumn{3}{|c|}{$\begin{array}{c}\text { Plumes with known concentration and } \\
\text { volume }\end{array}$} & \multirow{2}{*}{\multicolumn{2}{|c|}{$\begin{array}{c}\text { All plumes } \\
\text { Activity (pCi/l) }\end{array}$}} \\
\hline & & \multirow[b]{2}{*}{ 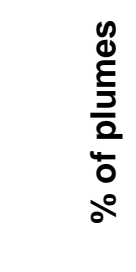 } & \multicolumn{2}{|c|}{ Activity (pCi/l) } & & \\
\hline & & & Maximum & $\begin{array}{c}\text { Above regulatory } \\
\text { limit }\end{array}$ & Maximum & $\begin{array}{l}\text { Above } \\
\text { regulatory } \\
\text { limit }\end{array}$ \\
\hline Tritium & 84 & 60 & $4,784,809$ & $4,779,627$ & $8,038,479$ & $8,029,774$ \\
\hline \multicolumn{7}{|c|}{ Radioisotopes } \\
\hline Tc & 16 & 81 & 7008.5 & & 8625.85 & \\
\hline $\mathrm{Sr}$ & 24 & 63 & 2705.6 & 2704 & 180.37 & 4326 \\
\hline$I^{*}$ & 8 & 88 & 5.19 & & 6 & \\
\hline $\mathrm{U}$ & 44 & 27 & 3.44 & 3 & 12.61 & 12 \\
\hline $\mathrm{Cs}^{*}$ & 3 & 33 & 1.4 & & 4.2 & \\
\hline $\mathrm{Ra}$ & 9 & 22 & 0.4 & 0 & 1.8 & 2 \\
\hline Gross Alpha & 3 & 100 & 0.91 & 0.9 & 0.91 & 0.9 \\
\hline Gross Beta & 1 & 100 & 0.6 & 0.4 & 0.6 & 0.4 \\
\hline $\begin{array}{l}\text { other (provide } \\
\text { names) }{ }^{\star}\end{array}$ & 1 & 100 & 0.03 & & 0.03 & \\
\hline $\mathrm{Pu}^{*}$ & 1 & 100 & 0.04 & & 0.04 & \\
\hline $\mathrm{Th}^{*}$ & 4 & 25 & 0.12 & & 0.48 & \\
\hline $\mathrm{Co}^{*}$ & 1 & 100 & 0 & & 0 & \\
\hline $\mathrm{Am}^{\star *}$ & 1 & 0 & & & & \\
\hline Carbon $14^{\star \star}$ & 1 & 0 & & & & \\
\hline $\begin{array}{l}\text { Total } \\
\text { radionuclides }\end{array}$ & 117 & & 9,726 & & 8,833 & \\
\hline
\end{tabular}


Table S11. Regulatory concentration limits used in calculations of the maximum mass/activity of contaminants in groundwater.

\begin{tabular}{|c|c|c|c|}
\hline Contaminants & 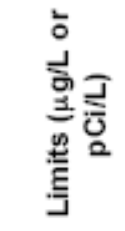 & 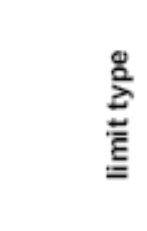 & Notes \\
\hline \multicolumn{4}{|c|}{ VOCs } \\
\hline PCE/TCE/NC/DCE/ & 5 & $\mathrm{MCL}$ & $\begin{array}{l}\text { PCE and TCE } \\
\text { CA VC MCL is } 0.5 \\
\text { For } 1,1 \text { DCE (most conservative DCE MCL). } \\
\text { CA MCL for } 1,1-D C E \text { \& cis-1,2-DCE is } 6 \text {. CA MCL for trans- } \\
1,2 \text { DCE is } 10 \text {. }\end{array}$ \\
\hline CT & 5 & $\mathrm{MCL}$ & $\mathrm{CA} M C L$ is 0.5 \\
\hline DCE & 7 & $\mathrm{MCL}$ & \\
\hline chloroform & 80 & $\mathrm{MCL}$ & for total trihalomethanes applied singly to chloroform \\
\hline $\mathrm{VC}$ & 2 & $\mathrm{MCL}$ & \\
\hline methylene chloride & 5 & $\mathrm{MCL}$ & Also called dichloromethane. Same as CA MCL \\
\hline TCA & 200 & $\mathrm{MCL}$ & $\begin{array}{l}\text { Standard for } 1,1,1-\mathrm{TCA} \text {. Same as CA MCL. CA MCL } \\
\text { for } 1,1,2-\mathrm{TCA} \text { is } 5 \text {. }\end{array}$ \\
\hline DCA & 5 & $\mathrm{MCL}$ & $\begin{array}{l}\text { Standard for } 1,2-D C A \text {. Same as CA MCL for } 1,1- \\
\text { DCA. } \\
\text { CA MCL for 1,2-DCA is } 0.5\end{array}$ \\
\hline carbon disulfide & 1600 & CARL & no $\mathrm{MCL}$ \\
\hline \multicolumn{4}{|c|}{ Fuel and Fuel Components } \\
\hline Benzene & 5 & $\mathrm{MCL}$ & CA MCL is 1 \\
\hline dichlorobenzene & 75 & $\mathrm{MCL}$ & $\begin{array}{l}\text { MCL for p-dichlorobenzene }(1,4-)-\text {-CA MCL }=5 . \mathrm{MCL} \text { for } \\
\text { o-dichlorobenzene }(1,2-)=600 \text {--the same as CA MCL. }\end{array}$ \\
\hline MTBE & 13 & CA MCL & no MCL \\
\hline Toluene & 1000 & $\mathrm{MCL}$ & CA MCL is 150 . \\
\hline ethylbenzene & 700 & $\mathrm{MCL}$ & CA MCL is 300 . \\
\hline \multicolumn{4}{|c|}{ Explosives } \\
\hline perchlorate & 60 & CARL & no $M C L$ \\
\hline \multicolumn{4}{|c|}{ Metals } \\
\hline $\mathrm{Fe}^{\dagger}$ & 300 & SDWS & CA SDWS is same. \\
\hline $\mathrm{Mn}^{\dagger}$ & 50 & SDWS & CA SDWS is same. \\
\hline $\mathrm{Cr}$ & 100 & $\mathrm{MCL}$ & CA MCL is 50 \\
\hline Bo & 10000 & CA RL & no $\mathrm{MCL}$ \\
\hline $\mathrm{Cr}-6^{*}$ & $\mathrm{NA}$ & & $\mathrm{Cr}-\mathrm{VI}$ is regulated under total $\mathrm{Cr} \mathrm{MCL}$. \\
\hline $\mathrm{Ba}$ & 2000 & $\mathrm{MCL}$ & CA MCL is 1000 \\
\hline
\end{tabular}




\begin{tabular}{|c|c|c|c|}
\hline $\mathrm{Ni}$ & 100 & $\mathrm{CA} M C L$ & no $M C L$ \\
\hline $\mathrm{Cu}^{\dagger}$ & 1000 & SDWS & CA SDWS is 1000 . TT is 1300. \\
\hline $\mathrm{Pb}$ & 15 & TT & \\
\hline As & 10 & $\mathrm{MCL}$ & As of $1 / 23 / 06$. CA MCL is 50 currently \\
\hline $\mathrm{Be}$ & 4 & $\mathrm{MCL}$ & same as CA MCL \\
\hline $\mathrm{Cd}$ & 5 & $\mathrm{MCL}$ & same as $\mathrm{CA} \mathrm{MCL}$ \\
\hline $\mathrm{Zn}^{\dagger}$ & 5000 & SDWS & CA SDWS is same. \\
\hline $\mathrm{Hg}$ & 2 & $\mathrm{MCL}$ & MCL for inorganic form. Same as CA MCL. \\
\hline $\mathrm{Al}^{\star \star}$ & 200 & $\begin{array}{c}\text { CA } \\
\text { SDWS }\end{array}$ & no $M C L$ \\
\hline$S e^{* k}$ & 50 & $\mathrm{MCL}$ & same as CA MCL \\
\hline$V^{* \star}$ & 500 & CARL & no MCL \\
\hline \multicolumn{4}{|c|}{ Tritium } \\
\hline Total tritium & 20,000 & CA MCL & no $M C L$ \\
\hline \multicolumn{4}{|c|}{ Radioisotopes } \\
\hline $\mathrm{Sr}$ & 8 & $\mathrm{CA} M C L$ & For Sr-90 \\
\hline $\mathrm{U}$ & 20 & CA MCL & $\begin{array}{l}\text { no MCL on activity basis. U MCL is on mass basis } \\
\text { and is utilized in metals group results. }\end{array}$ \\
\hline $\mathrm{Ra}$ & 5 & $\mathrm{MCL}$ & same as CA MCL \\
\hline Gross Alpha & 15 & MCL & $\begin{array}{l}\text { same as CA MCL except CA standard is for alpha } \\
\text { excluding that } \\
\text { from } \mathrm{Ra} \text { and } \mathrm{U} \text {. }\end{array}$ \\
\hline Gross Beta & 50 & CA MCL & $\mathrm{MCL}$ is in unites of millirems/year. \\
\hline \multicolumn{4}{|c|}{ Sulfates and nitrates } \\
\hline Nitrates & 10 & $\mathrm{MCL}$ & \\
\hline Sulfates $^{\dagger}$ & 250,000 & SDWS & \\
\hline
\end{tabular}


Table S12. The basic groups of plume characteristics used in the FMA.

\begin{tabular}{|l|l|l|l|}
\hline $\begin{array}{l}\text { Groups of plume } \\
\text { characteristics }\end{array}$ & $\begin{array}{l}\text { Qualitative or } \\
\text { quantitative } \\
\text { data }\end{array}$ & $\begin{array}{l}\text { Number of data } \\
\text { categories }\end{array}$ & $\begin{array}{l}\text { Main (1) or } \\
\text { supplementary (0) } \\
\text { data }\end{array}$ \\
\hline $\begin{array}{l}\text { Contaminant } \\
\text { groups (Cntm) }\end{array}$ & Qualitative 8 & 1 \\
\hline Severity index (Sv) & Quantitative & 2 & 1 \\
\hline $\begin{array}{l}\text { Plume volume } \\
\text { (Vol) }\end{array}$ & Quantitative 1 & & 1 \\
\hline $\begin{array}{l}\text { Depth and } \\
\text { Velocity (Dp+V) }\end{array}$ & Quantitative 2 & & 0 \\
\hline Climate Qualita & tive & 1 & 0 \\
\hline
\end{tabular}


Table S13. Results of multiple factor analysis of groundwater plumes

(a) Descriptive statistics of data groups

\begin{tabular}{|c|c|c|c|c|c|}
\hline Variable & Number of sites *) & Minimum & Maximum & Mean & Std. deviation \\
\hline Ngr & 124 & 1.000 & 6.000 & 2.742 & 1.182 \\
\hline Sv & 124 & 1.000 & 16.000 & 10.258 & 6.405 \\
\hline Vol & 124 & 4.699 & 10.544 & 7.535 & 1.184 \\
\hline $\mathrm{Dp}$ & 124 & 0.778 & 3.627 & 1.888 & 0.504 \\
\hline Vel & 124 & 0.000 & 3.699 & 2.130 & 0.732 \\
\hline
\end{tabular}

(b) Frequences of qualitative groups

\begin{tabular}{lrrrr}
\hline & Variable & Present- 1, Absent- 0 & Frequencies & \multicolumn{1}{c}{$\%$} \\
\hline VOCs & 0 & 27 & 21.774 \\
& 1 & 97 & 78.226 \\
\hline Fl & 0 & 112 & 90.323 \\
& & 12 & 9.677 \\
\hline Expl & 1 & 112 & 90.323 \\
& & 12 & 9.677 \\
\hline $\mathrm{Mt}$ & 1 & 80 & 64.516 \\
& $\mathrm{H} 3$ & 0 & 44 & 35.484 \\
& 1 & 73 & 58.871 \\
$\mathrm{RI}$ & 0 & 51 & 41.129 \\
\hline $\mathrm{SO} 4$ & 1 & 85 & 68.548 \\
& 0 & 39 & 31.452 \\
\hline $\mathrm{NO} 3$ & 1 & 87 & 70.161 \\
& 0 & 37 & 29.839 \\
$\mathrm{Cl}$ & 1 & 76 & 61.290 \\
& 0 & 48 & 38.710 \\
\hline
\end{tabular}

(c) Correlation matrix - Pearson correlation coefficients

\begin{tabular}{|c|c|c|c|c|c|}
\hline Variables & $\mathrm{Ngr}$ & Sv & Vol & $\mathrm{Dp}$ & Vel \\
\hline Ngr & 1 & 0.583 & -0.111 & 0.312 & 0.101 \\
\hline Sv & 0.583 & 1 & -0.025 & 0.342 & 0.132 \\
\hline Vol & -0.111 & -0.025 & 1 & -0.035 & -0.101 \\
\hline $\mathrm{Dp}$ & 0.312 & 0.342 & -0.035 & 1 & 0.101 \\
\hline Vel & 0.101 & 0.132 & -0.101 & 0.101 & 1 \\
\hline
\end{tabular}


(d) Burt tableof contaminat graps

\begin{tabular}{|c|c|c|c|c|c|c|c|c|c|c|c|c|}
\hline & VOCSO & Vos 1 & $\mathrm{~A}-0$ & F-1 & Exd-0 & Expl-1 & $\mathrm{M}-0$ & $\mathrm{M}-1$ & $\mathrm{HBO}$ & HB-1 & $\mathrm{A}-0$ & $\mathrm{~A}-1$ \\
\hline vocso & 27 & 0 & 23 & 4 & 24 & 3 & 13 & 14 & 12 & 15 & 13 & 14 \\
\hline$v 00 s-1$ & 0 & 97 & 89 & 8 & 88 & 9 & 67 & 30 & ๓1 & 36 & 72 & 25 \\
\hline$\overline{\mathrm{F} 0}$ & 23 & 89 & 112 & q & 100 & 12 & 72 & 40 & 64 & 48 & 77 & 35 \\
\hline \#-1 & 4 & 8 & 0 & 12 & 12 & d & 8 & 4 & 9 & 3 & 8 & 4 \\
\hline Exd-0 & 24 & 88 & 100 & 12 & 112 & 0 & 71 & 41 & 64 & 48 & 74 & 38 \\
\hline Exd-1 & 3 & 9 & 12 & d & 0 & 12 & 9 & 3 & 9 & 3 & 11 & 1 \\
\hline $\mathrm{M}=0$ & 13 & 67 & 72 & 8 & 71 & 9 & 80 & q & 51 & 29 & 58 & 22 \\
\hline M-1 & 14 & 30 & 40 & 4 & 41 & 3 & 0 & 44 & 22 & 22 & 27 & 17 \\
\hline$\overline{\mathrm{HBO}}$ & 12 & 61 & 64 & 9 & 64 & 9 & 51 & 22 & 73 & 0 & 6 & $\overline{13}$ \\
\hline HB-1 & 15 & 36 & 48 & 3 & 48 & 3 & 29 & 22 & 0 & 51 & 25 & 26 \\
\hline$\overline{\mathrm{A}-0}$ & 13 & 72 & 77 & 8 & 74 & 11 & 58 & 27 & 60 & 25 & 85 & $\overline{0}$ \\
\hline R-1 & 14 & 25 & 35 & 4 & 38 & 1 & 22 & 17 & 13 & 26 & 0 & 39 \\
\hline$\overline{\mathrm{SO} 40}$ & 22 & 65 & 76 & 11 & 75 & 12 & 6 & 25 & 48 & 39 & 50 & 37 \\
\hline $\mathrm{SOA} 1$ & 5 & 32 & 36 & 1 & 37 & d & 18 & 19 & २ & 12 & 35 & 2 \\
\hline$\overline{\mathrm{NOBO}}$ & 15 & 61 & 66 & 19 & 72 & 4 & 50 & 26 & 46 & 30 & 53 & $\overline{23}$ \\
\hline NOB-1 & 12 & 36 & 46 & 2 & 40 & 8 & 30 & 18 & 27 & 21 & 32 & 16 \\
\hline
\end{tabular}

(e) Egenvalues and percentages of factors

\begin{tabular}{|c|c|c|c|c|c|c|c|c|c|c|}
\hline & $\mathrm{F} 1$ & $\mathrm{~F} 2$ & $\mathrm{~F} 3$ & $F 4$ & Ђ & 16 & $\mathrm{~F}$ & F8 & F9 & $\mathrm{F} 10$ \\
\hline Egendue & 1748 & 1220 & 0.949 & 0.684 & 0.601 & 0.554 & 0.459 & 0.378 & 0.172 & 0.070 \\
\hline Variability $(\%)$ & 25573 & 17..53 & 13893 & 10.009 & 8793 & 8104 & 6.710 & 5.535 & 2512 & 1031 \\
\hline Amlative $\%$ & 25573 & 43426 & 57.308 & 67.317 & 76110 & 84.214 & 90.923 & 96458 & 98.969 & 100,000 \\
\hline
\end{tabular}

\section{(f) LgandR/œefficients}

\begin{tabular}{|c|c|c|c|c|c|c|}
\hline & Cntm & St & Vd & $\mathrm{Dp}+\mathrm{V}$ & d & MFA \\
\hline $\mathrm{atm}$ & 3138 & 0.783 & 0.088 & 0.349 & 0.207 & 2294 \\
\hline So & 0.783 & 1070 & 0.008 & 0.139 & 0.026 & 1065 \\
\hline vol & 0.088 & 0.008 & 100 & 0.010 & 0.010 & 0.27 \\
\hline $\mathrm{Dp}+\mathrm{V}$ & 0.349 & 0.139 & 0.010 & 1667 & 0.018 & 0.285 \\
\hline a & 0.207 & 0.026 & 0.010 & 0.018 & 1000 & 0.139 \\
\hline MFA & 2294 & 1065 & 0.27 & 0.285 & 0.139 & 2281 \\
\hline
\end{tabular}

RVoefficients

\begin{tabular}{|c|c|c|c|c|c|c|}
\hline & antm & SV & $\mathrm{Vd}$ & $\overline{D p+V}$ & $\bar{d}$ & MFA \\
\hline $\mathrm{Ctm}$ & 1000 & 0.427 & 0.050 & 0.152 & 0.117 & 0.87 \\
\hline So & 0.427 & 1000 & 0.08 & 0.104 & 0.025 & 062 \\
\hline Vol & 0.060 & 0.008 & 100 & 0.008 & 0.010 & 0.415 \\
\hline$\overline{p p+V}$ & 0.152 & 0.104 & 0.008 & 100 & 0.014 & 0.146 \\
\hline a & 0.117 & 0.025 & 0.010 & 0.014 & 1000 & 0.002 \\
\hline MFA & 0.87 & 0.682 & 0.415 & 0.146 & 0.092 & 100 \\
\hline
\end{tabular}

\section{(d) Conelations betweenveriables andfactors}

\begin{tabular}{|c|c|c|c|c|c|c|c|c|c|c|}
\hline & F1 & $\mathrm{F} 2$ & F3 & F4 & Б & F6 & $\mathrm{F}$ & F8 & F9 & $\mathrm{F} 10$ \\
\hline $\mathrm{Ng}$ & 0.858 & -0.147 & 0.373 & -0.026 & 0.046 & 0.300 & -0.035 & 0.053 & -0.026 & -0.080 \\
\hline St & 0.842 & 0.343 & -0.072 & 0.184 & -0.046 & -0.126 & -0.183 & -0.130 & -0.090 & 0.242 \\
\hline Vol & -0.250 & 0.725 & 0.51 & 0.194 & 0.029 & 0.048 & 0.251 & 0.068 & 0.011 & 0.014 \\
\hline $\mathrm{DP}$ & 0.430 & 0.000 & 0.006 & 0.168 & -0.006 & -0.218 & 0.186 & 0.046 & -0.054 & -0.177 \\
\hline Vel & 0.191 & 0.078 & -0.094 & -0.330 & -0.022 & -0.048 & 0.039 & -0.044 & 0.146 & 0.026 \\
\hline
\end{tabular}


(h) Factorscorrespondhg to duster centroids (fromk-means clustering)

\begin{tabular}{cccccc}
\hline Custer & $\mathrm{F} 1$ & & $\mathrm{~F} 2$ & $\mathrm{~F} 3$ & $\mathrm{~F} 4$ \\
\hline 1 & & 0.213 & 0.135 & 0.098 & 0.068 \\
2 & & 0.124 & 0.063 & 0.410 & 0.073 \\
3 & & 0.701 & 0.070 & 0.064 & 0.034 \\
4 & & 0.085 & 0.580 & 0.064 & 0.032 \\
5 & & 0.100 & 0.070 & 0.095 & 0.409 \\
\hline
\end{tabular}

(i) dassification of plumesinto5dusters (plumenames corresponding to plumecodesaregiven in Table S1)

\begin{tabular}{|c|c|c|c|c|}
\hline Quster 1 & Guster 2 & Quster3 & Custer 4 & Guster5 \\
\hline 11 & 12 & 6 & 178 & 29 \\
\hline 13 & 7 & 134 & 180 & 41 \\
\hline 15 & 14 & 189 & 181 & 48 \\
\hline 179 & 144 & 22 & 190 & 49 \\
\hline 191 & 43 & 24 & 16 & 50 \\
\hline 17 & 56 & 25 & 18 & 51 \\
\hline 143 & 195 & 28 & 19 & 57 \\
\hline 23 & 204 & 31 & 20 & 192 \\
\hline 26 & 205 & 32 & 21 & 217 \\
\hline 27 & 208 & 42 & 35 & 61 \\
\hline 30 & 65 & 47 & 193 & ๔3 \\
\hline 33 & 66 & 226 & 197 & 70 \\
\hline 34 & 225 & 58 & 198 & 22 \\
\hline 36 & 85 & 210 & 200 & 223 \\
\hline 37 & 156 & 212 & 206 & 110 \\
\hline 38 & 87 & 214 & 207 & \\
\hline 39 & & $\overline{216}$ & 209 & \\
\hline 145 & & 59 & 211 & \\
\hline 44 & & 67 & 219 & \\
\hline 45 & & 220 & 64 & \\
\hline 46 & & 221 & 156 & \\
\hline 227 & & 78 & 157 & \\
\hline 228 & & 86 & 98 & \\
\hline 52 & & 99 & & \\
\hline 53 & & 109 & & \\
\hline 54 & & & & \\
\hline 55 & & & & \\
\hline 194 & & & & \\
\hline 196 & & & & \\
\hline 199 & & & & \\
\hline 201 & & & & \\
\hline 202 & & & & \\
\hline 203 & & & & \\
\hline 213 & & & & \\
\hline 218 & & & & \\
\hline 60 & & & & \\
\hline 62 & & & & \\
\hline 224 & & & & \\
\hline 71 & & & & \\
\hline 81 & & & & \\
\hline 82 & & & & \\
\hline 83 & & & & \\
\hline 84 & & & & \\
\hline 88 & & & & \\
\hline 90 & & & & \\
\hline
\end{tabular}


Table S14. Results of multiple factor analysis of groundwater plumes with $\mathrm{CCl} 4$ concentrations

(a) Descriptive statistics of data groups

\begin{tabular}{|c|c|c|c|c|c|}
\hline Variable & Observations*) & Minimum & Maximum & Mean & Std. deviation \\
\hline Ngr & 26 & 2.000 & 5.000 & 3.423 & 0.987 \\
\hline Sv & 26 & 2.000 & 16.000 & 10.462 & 6.408 \\
\hline Vol & 26 & 5.272 & 9.872 & 7.143 & 1.023 \\
\hline $\mathrm{CCl} 4$ r & 26 & 0.200 & 1380.000 & 84.085 & 296.050 \\
\hline $\mathrm{Dp}$ & 26 & 1.000 & 2.778 & 2.069 & 0.311 \\
\hline Vel & 26 & 1.000 & 3.301 & 1.881 & 0.571 \\
\hline
\end{tabular}

$\left.{ }^{\star}\right) 26$ is the number of sites with all groups of data

(b) Frequences of qualitative groups

\begin{tabular}{lrrr}
\hline Variable & Categories & Frequencies & \multicolumn{1}{c}{$\%$} \\
\hline VOCs & 1 & 26 & 100.000 \\
\hline Fl & 0 & 24 & 92.308 \\
& 1 & 2 & 7.692 \\
\hline Expl & 0 & 26 & 100.000 \\
\hline $\mathrm{Mt}$ & 0 & 16 & 61.538 \\
& 1 & 10 & 38.462 \\
\hline $\mathrm{H} 3$ & 0 & 13 & 50.000 \\
& 1 & 13 & 50.000 \\
\hline $\mathrm{Rl}$ & 0 & 22 & 84.615 \\
& 1 & 4 & 15.385 \\
\hline SO4 & 0 & 9 & 34.615 \\
& 1 & 17 & 65.385 \\
\hline NO3 & 0 & 9 & 34.615 \\
& 1 & 17 & 65.385 \\
\hline $\mathrm{Cl}$ & 1 & 25 & 96.154 \\
& 2 & 1 & 3.846 \\
\hline
\end{tabular}

(c) Correlation matrix - Pearson correlation coefficients

\begin{tabular}{l|rr|r|rr|r|}
\hline Variables & Ngr & Sv & \multicolumn{1}{l|}{ Vol } & \multicolumn{1}{c|}{ CCl4 } & \multicolumn{1}{c|}{ Dp } & \multicolumn{1}{c|}{ Vel } \\
\hline Ngr & $\mathbf{1}$ & 0.563 & -0.344 & -0.019 & 0.285 & 0.127 \\
Sv & 0.563 & $\mathbf{1}$ & -0.160 & 0.042 & 0.127 & 0.373 \\
\hline Vol & -0.344 & -0.160 & $\mathbf{1}$ & -0.175 & -0.392 & -0.320 \\
\hline CCl4 & -0.019 & 0.042 & -0.175 & $\mathbf{1}$ & 0.023 & 0.228 \\
Dp & 0.285 & 0.127 & -0.392 & 0.023 & $\mathbf{1}$ & 0.691 \\
\hline Vel & 0.127 & 0.373 & -0.320 & 0.228 & 0.691 & $\mathbf{1}$ \\
\hline
\end{tabular}

(d) Eigenvalues and percentages of factors

\begin{tabular}{lrrrrrrrrr}
\hline & F1 & \multicolumn{1}{c}{ F2 } & \multicolumn{1}{c}{ F3 } & \multicolumn{1}{c}{ F4 } & \multicolumn{1}{c}{ F5 } & \multicolumn{1}{r}{ F6 } & \multicolumn{1}{r}{ F7 } & \multicolumn{1}{r}{ F8 } & F9 \\
\hline Eigenvalue & 1.734 & 1.471 & 1.062 & 0.701 & 0.456 & 0.234 & 0.190 & 0.055 & 0.008 \\
Variability & 29.336 & 24.887 & 17.963 & 11.860 & 7.716 & 3.951 & 3.220 & 0.928 & 0.139 \\
Cumulative & 29.336 & 54.224 & 72.187 & 84.047 & 91.762 & 95.713 & 98.933 & 99.861 & 100.000 \\
\hline
\end{tabular}

(e) Correlations between variables and factors

\begin{tabular}{lccccccccc}
\hline & F1 & F2 & F3 & F4 & F5 & F6 & F7 & F8 & F9 \\
\hline Cntm & 0.488 & 0.698 & 0.438 & 0.350 & 0.247 & 0.201 & 0.152 & 0.052 & 0.004 \\
Sv & 0.710 & 0.063 & 0.379 & 0.047 & 0.029 & 0.030 & 0.017 & 0.001 & 0.004 \\
Vol & 0.523 & 0.048 & 0.225 & 0.041 & 0.157 & 0.002 & 0.004 & 0.001 & 0.000 \\
CCl4 & 0.014 & 0.661 & 0.020 & 0.264 & 0.022 & 0.001 & 0.017 & 0.000 & 0.000 \\
\hline Dp+V & 0.240 & 0.137 & 0.043 & 0.215 & 0.172 & 0.173 & 0.028 & 0.018 & 0.003 \\
Cl & 0.000 & -0.042 & -0.038 & -0.129 & -0.013 & -0.015 & -0.049 & -0.052 & 0.000 \\
\hline
\end{tabular}


(f) Lg and RV coefficients

Lg coefficients:

\begin{tabular}{lccccccc}
\hline & Cntm & Sv & Vol & CCl4 & Dp+V & Cl & MFA \\
\hline Cntm & 1.785 & 0.611 & 0.194 & 0.185 & 0.661 & 0.193 & 1.601 \\
Sv & 0.611 & 1.078 & 0.092 & 0.001 & 0.096 & 0.025 & 1.028 \\
Vol & 0.194 & 0.092 & 1.000 & 0.031 & 0.151 & 0.002 & 0.759 \\
CCl4 & 0.185 & 0.001 & 0.031 & 1.000 & 0.031 & 0.003 & 0.702 \\
\hline Dp+V & 0.661 & 0.096 & 0.151 & 0.031 & 1.033 & 0.096 & 0.542 \\
Cl & 0.193 & 0.025 & 0.002 & 0.003 & 0.096 & 1.000 & 0.128 \\
\hline MFA & 1.601 & 1.028 & 0.759 & 0.702 & 0.542 & 0.128 & 2.358 \\
\hline
\end{tabular}

RV coefficients:

\begin{tabular}{lccccccr}
\hline & Cntm & Sv & Vol & CCl4 & Dp + V & Cl & MFA \\
\hline Cntm & 1.000 & 0.440 & 0.145 & 0.139 & 0.487 & 0.144 & 0.780 \\
Sv & 0.440 & 1.000 & 0.089 & 0.001 & 0.091 & 0.024 & 0.645 \\
Vol & 0.145 & 0.089 & 1.000 & 0.031 & 0.149 & 0.002 & 0.494 \\
CCl4 & 0.139 & 0.001 & 0.031 & 1.000 & 0.031 & 0.003 & 0.457 \\
\hline Dp+V & 0.487 & 0.091 & 0.149 & 0.031 & 1.000 & 0.094 & 0.347 \\
Cl & 0.144 & 0.024 & 0.002 & 0.003 & 0.094 & 1.000 & 0.083 \\
\hline MFA & 0.780 & 0.645 & 0.494 & 0.457 & 0.347 & 0.083 & 1.000 \\
\hline
\end{tabular}

(g) Factors correspondng to cluster centroids ( $k$-means clustering)

\begin{tabular}{crrr}
\hline Cluster & \multicolumn{1}{l}{ F1 } & \multicolumn{1}{l}{ F2 } & \multicolumn{1}{c}{ F3 } \\
\hline 1 & 1.535 & 1.135 & 0.003 \\
2 & -1.038 & 0.143 & 1.177 \\
3 & -1.108 & 0.644 & 0.118 \\
4 & 1.327 & -0.953 & 0.890 \\
5 & -0.397 & -0.544 & -1.548 \\
\hline
\end{tabular}

(h) Classification of plumes into 5 clusters (numbers are plume codes given in Table S1)

\begin{tabular}{|c|c|c|c|c|c|}
\hline Cluster & 1 & 2 & 3 & 4 & 5 \\
\hline & 26 & 37 & 44 & 57 & 197 \\
\hline & \multirow[t]{7}{*}{27} & 41 & 53 & 58 & 200 \\
\hline & & 49 & 54 & 193 & 203 \\
\hline & & 81 & 202 & 194 & 204 \\
\hline & & & & 205 & 206 \\
\hline & & & & 212 & 207 \\
\hline & & & & 214 & 211 \\
\hline & & & & 216 & 219 \\
\hline
\end{tabular}




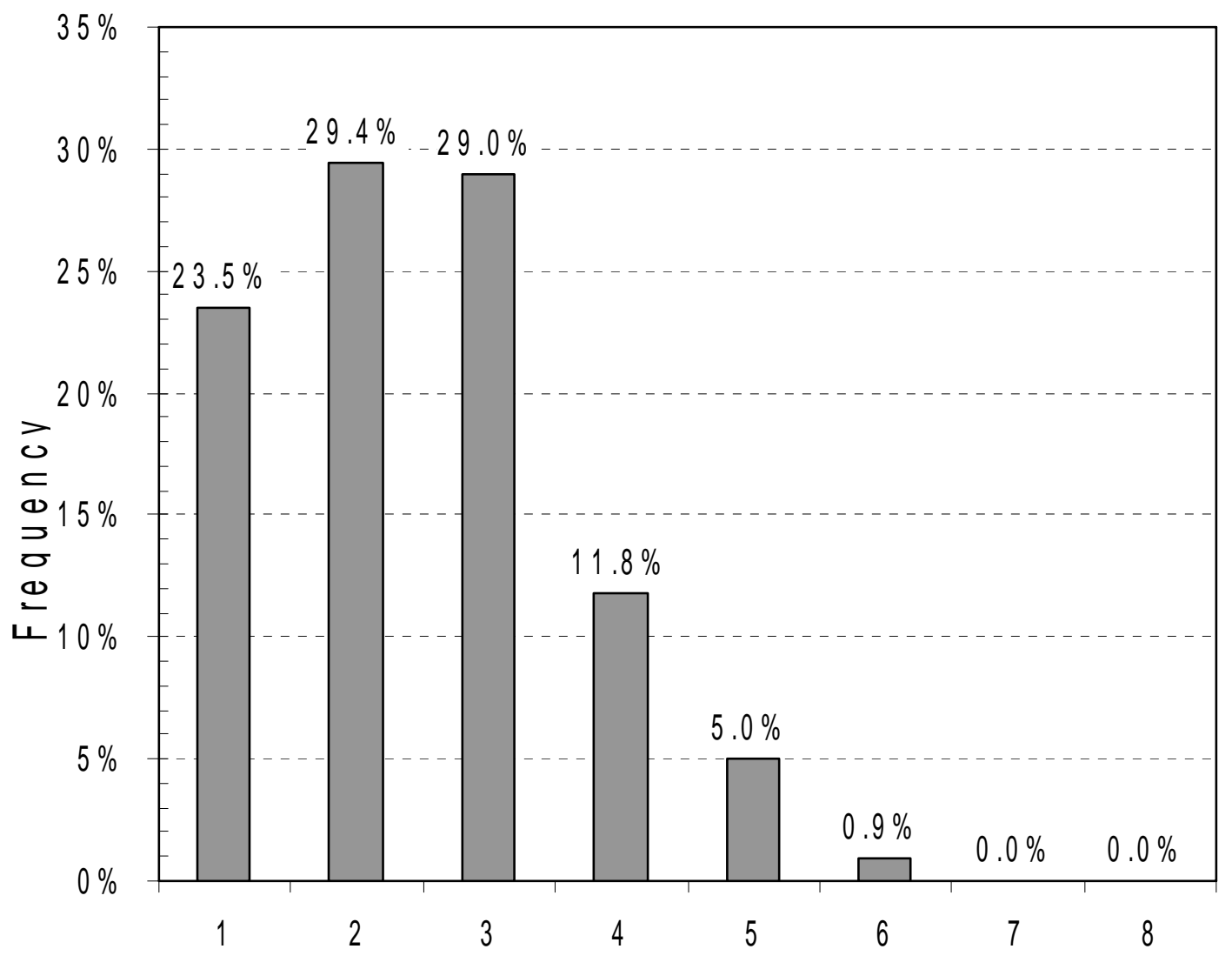

Number of contaminant groups in plumes

Figure S1. Frequency of occurrence of contaminant groups in groundwater plumes. 

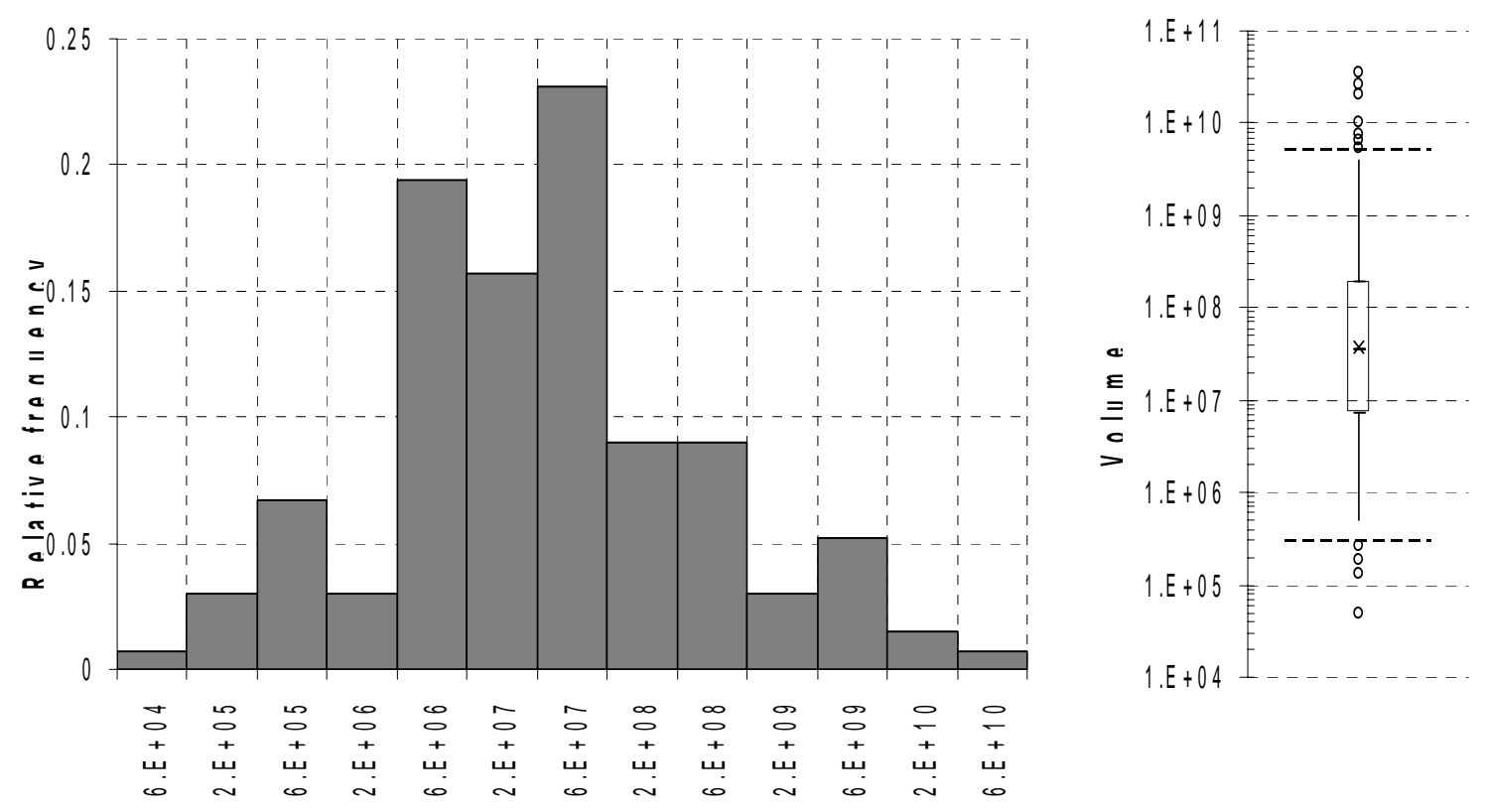

Volum e

Figure S2. (a) Relative frequency of plume volumes: bin values shown are midpoints of $\log$ of volume (in $\mathrm{m}^{3}$ ); (b) Box plot of log plume volumes. The mean is labeled as “x," the median as “-“, the whiskers are shown as Q1-1.5(Q3-Q1) and Q3+1.5(Q3Q1), and the outliers are shown by open circles. 
(a) Chlorinated Hydrocarbons

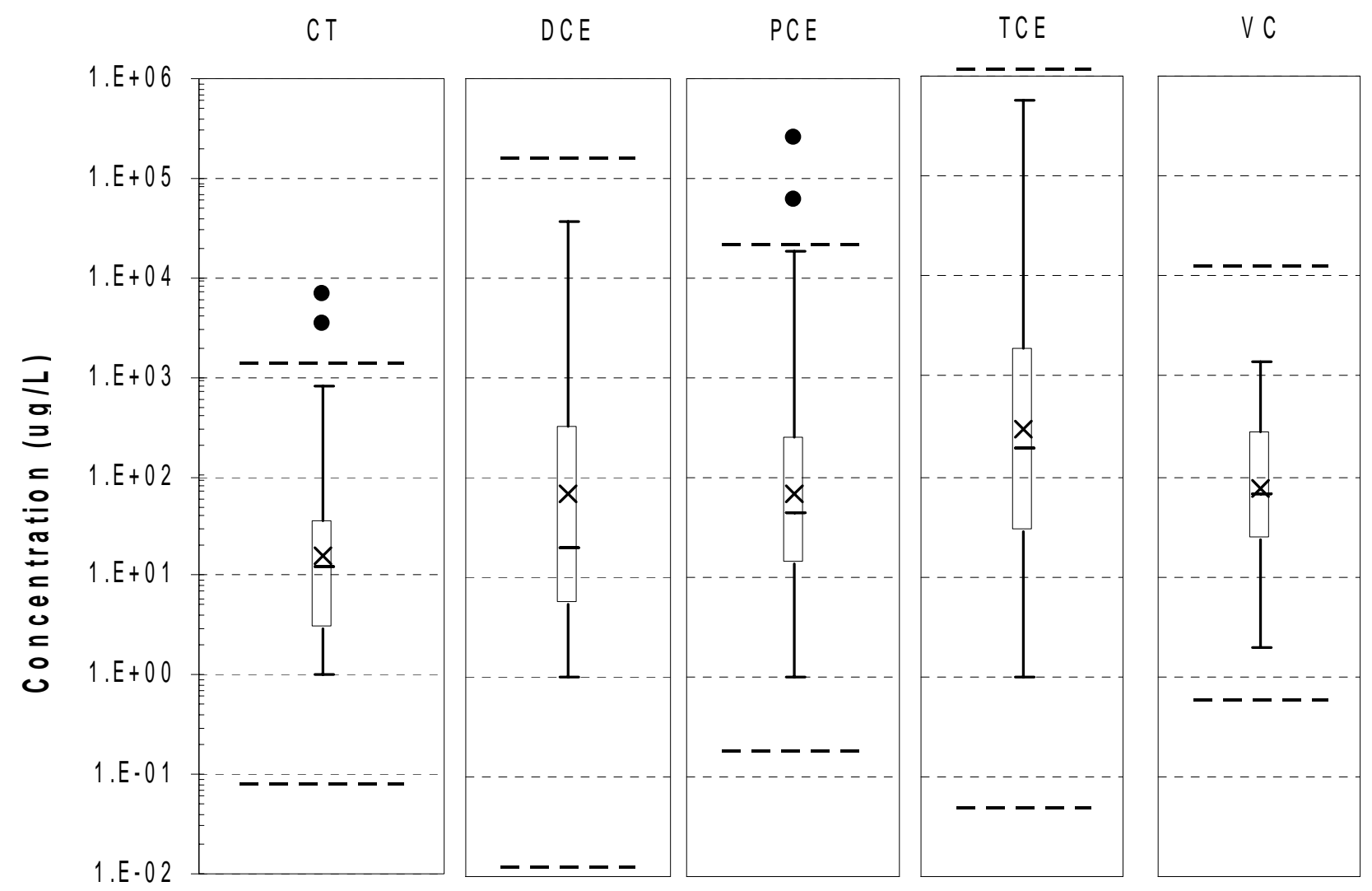




\section{(b) Metals and radioisotopes}

Cr
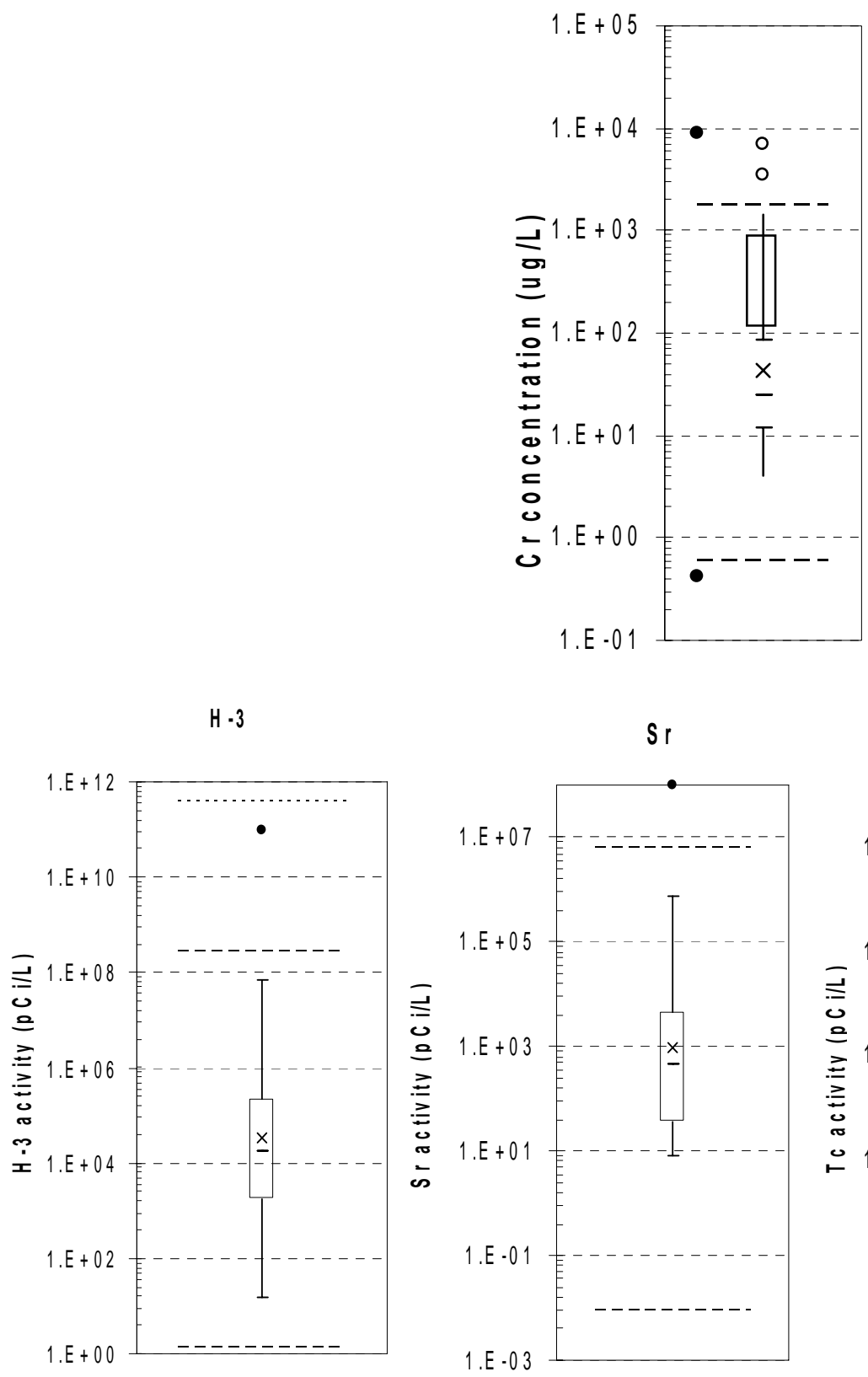

T C

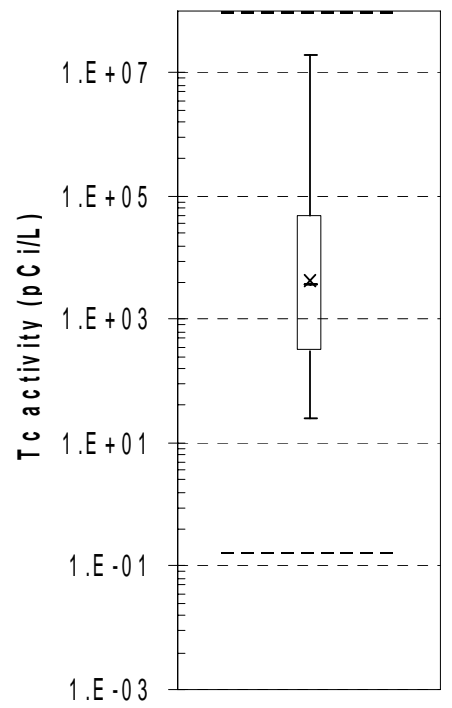

U

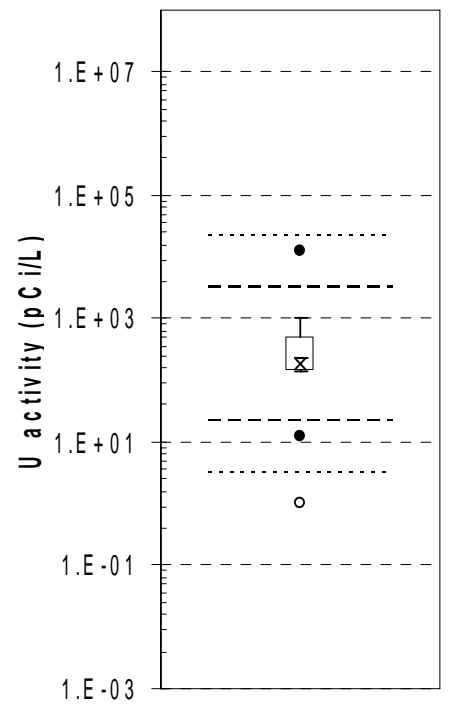


(c) Sulfates and nitrates

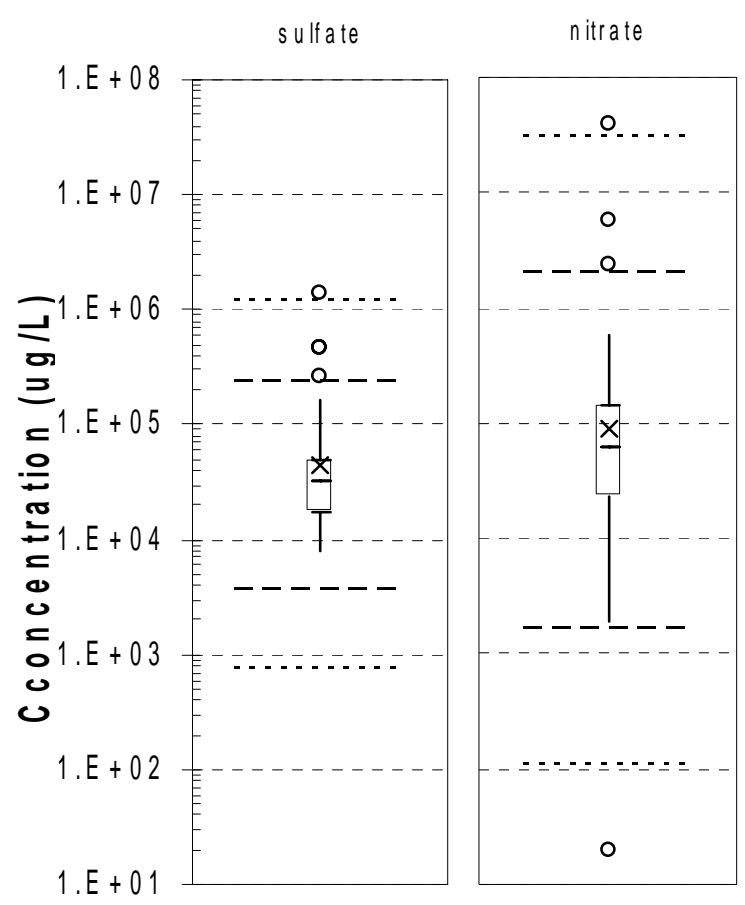

Figure S3. Box-and-whiskers plots of maximum concentrations of contaminants: the mean is shown by a symbol " $x$ ", the median by a symbol "_“, the whiskers are shown as Q1-1.5(Q3-Q1) and Q3+1.5(Q3-Q1), and the outliers are shown by open circles. Solid circles are minimum and maximum concentrations from Riley and Zachara (1992). 

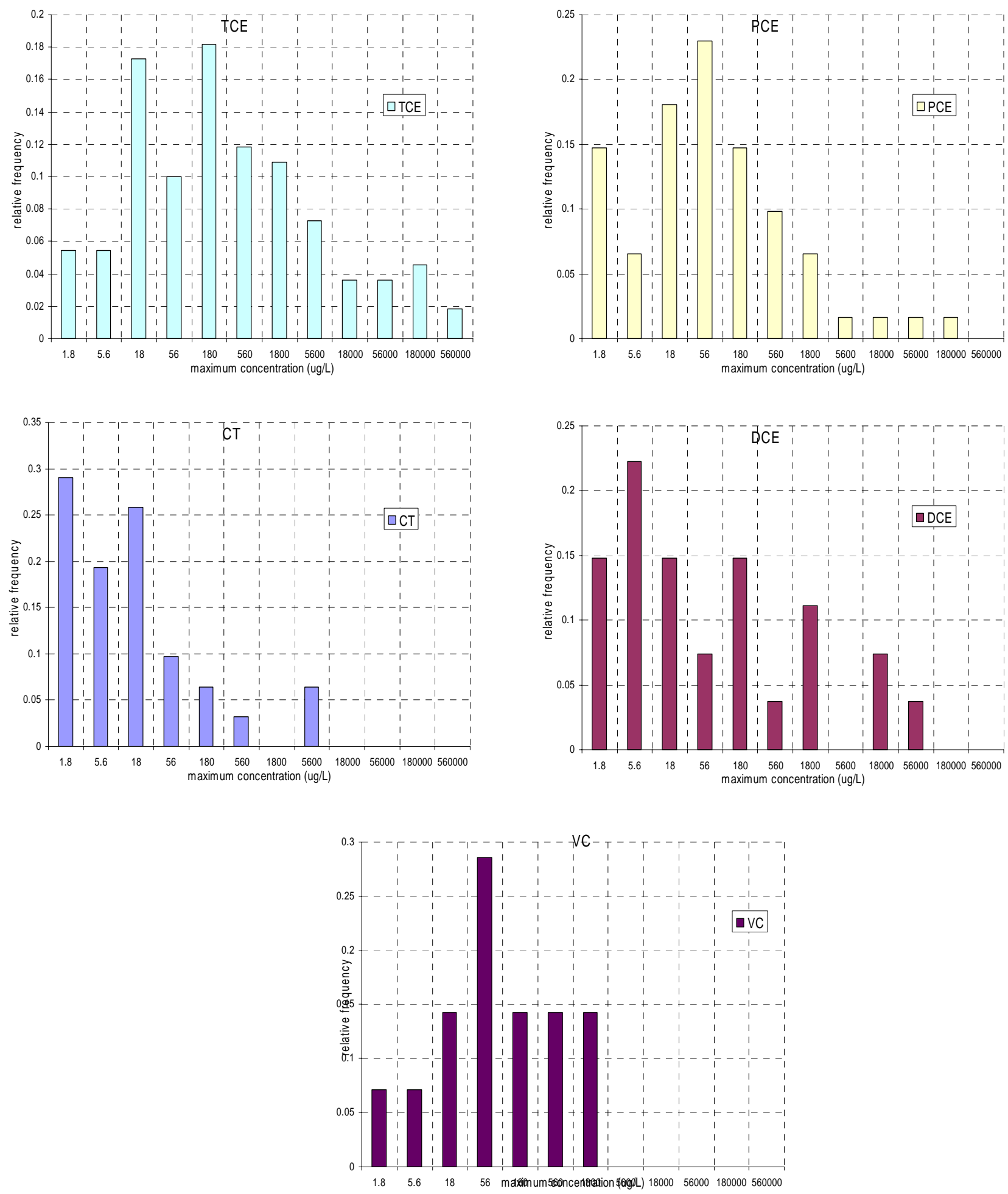

Figure S4. Relative frequency of the maximum concentrations of chlorinated hydrocarbons. Note bin values are midpoints in log space. 


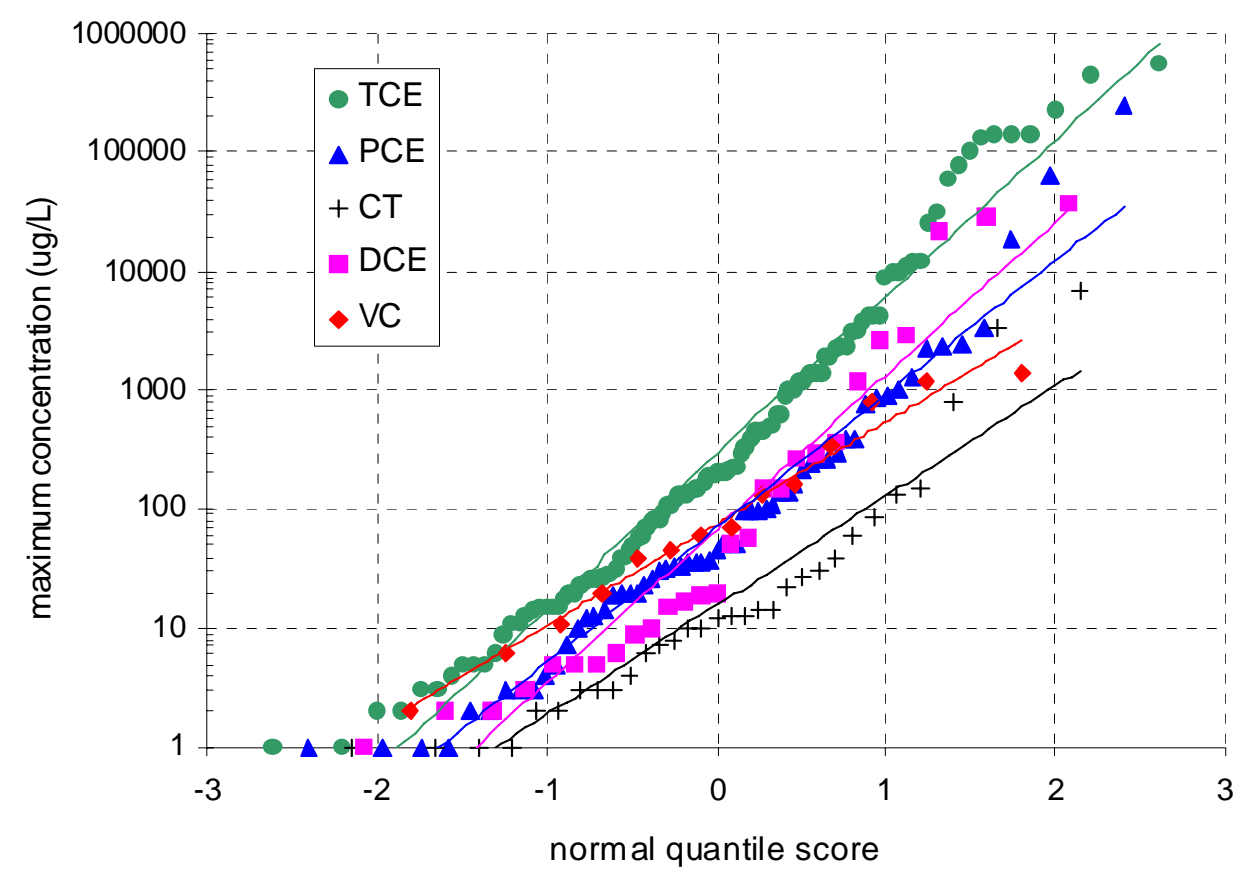

Figure S5. Plots of a normal quantile score vs. maximum concentrations of chlorinated hydrocarbons. 

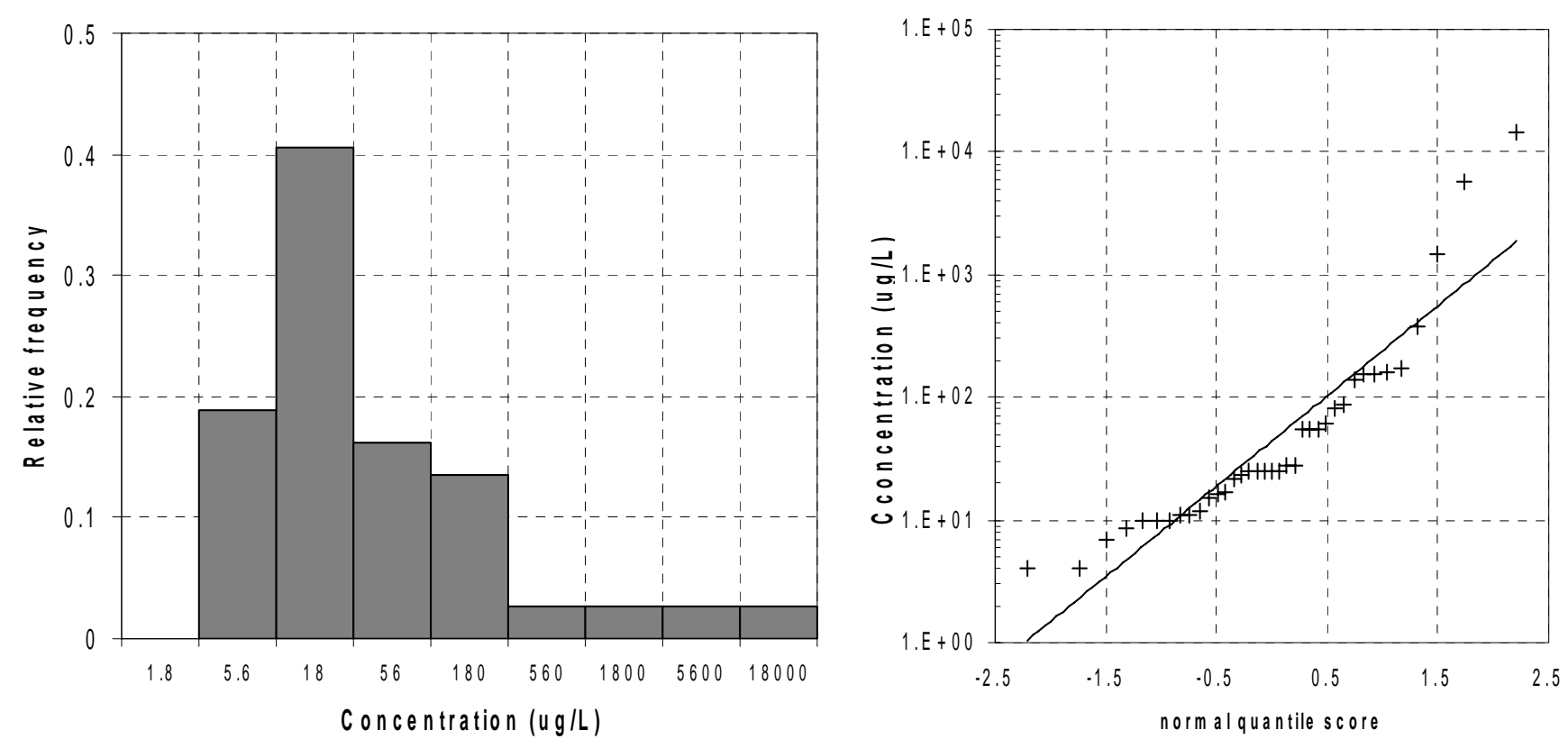

Figure S6. Relative frequency and a normal quantile score vs. maximum Cr concentrations. Bin values are midpoints in log space. 

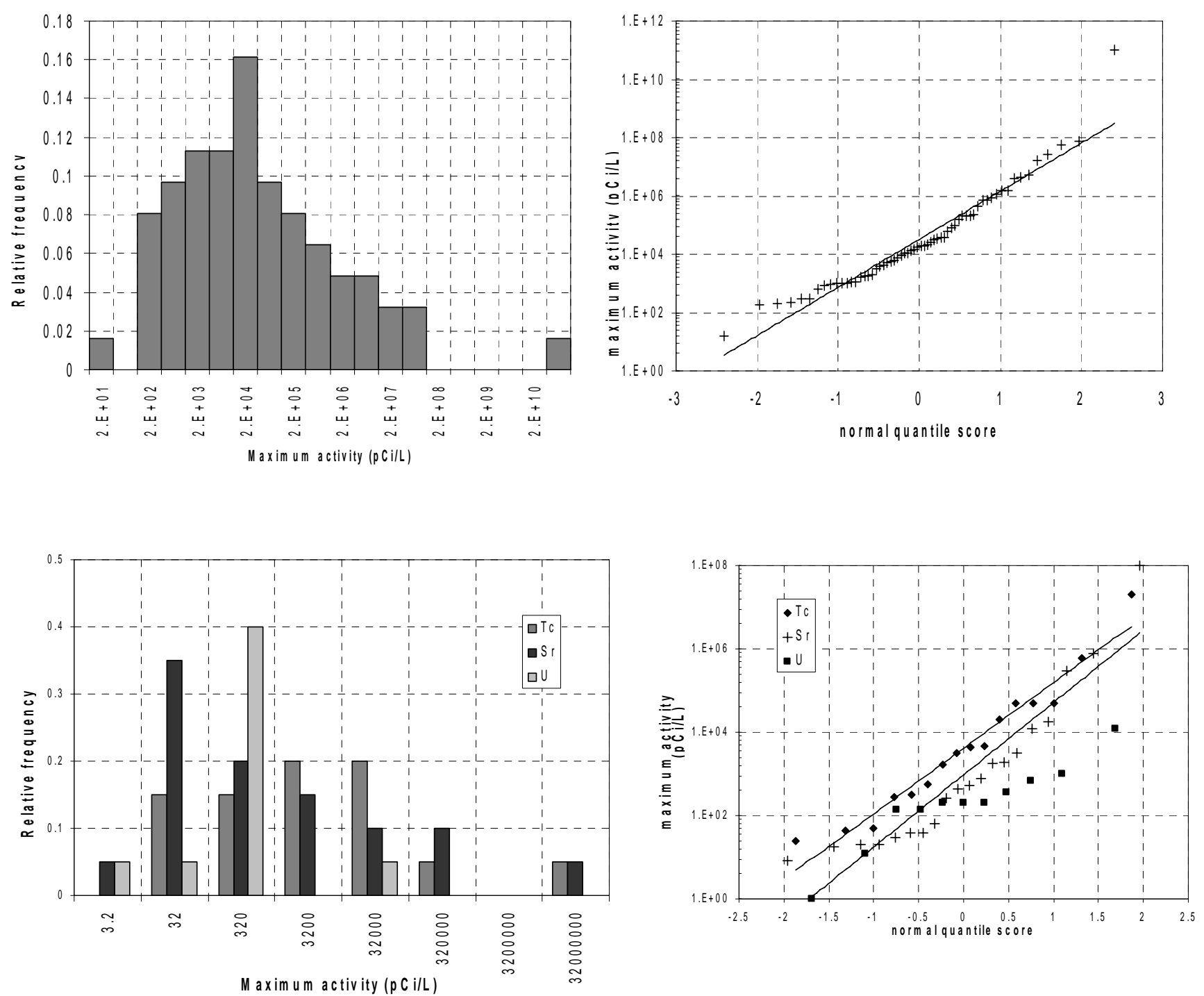

Figure S7. Relative frequency and a normal quantile score vs. maximum ${ }^{3} \mathbf{H}, \mathrm{Sr}$, Tc, and $U$ concentrations. Bin values are midpoints in log space. 

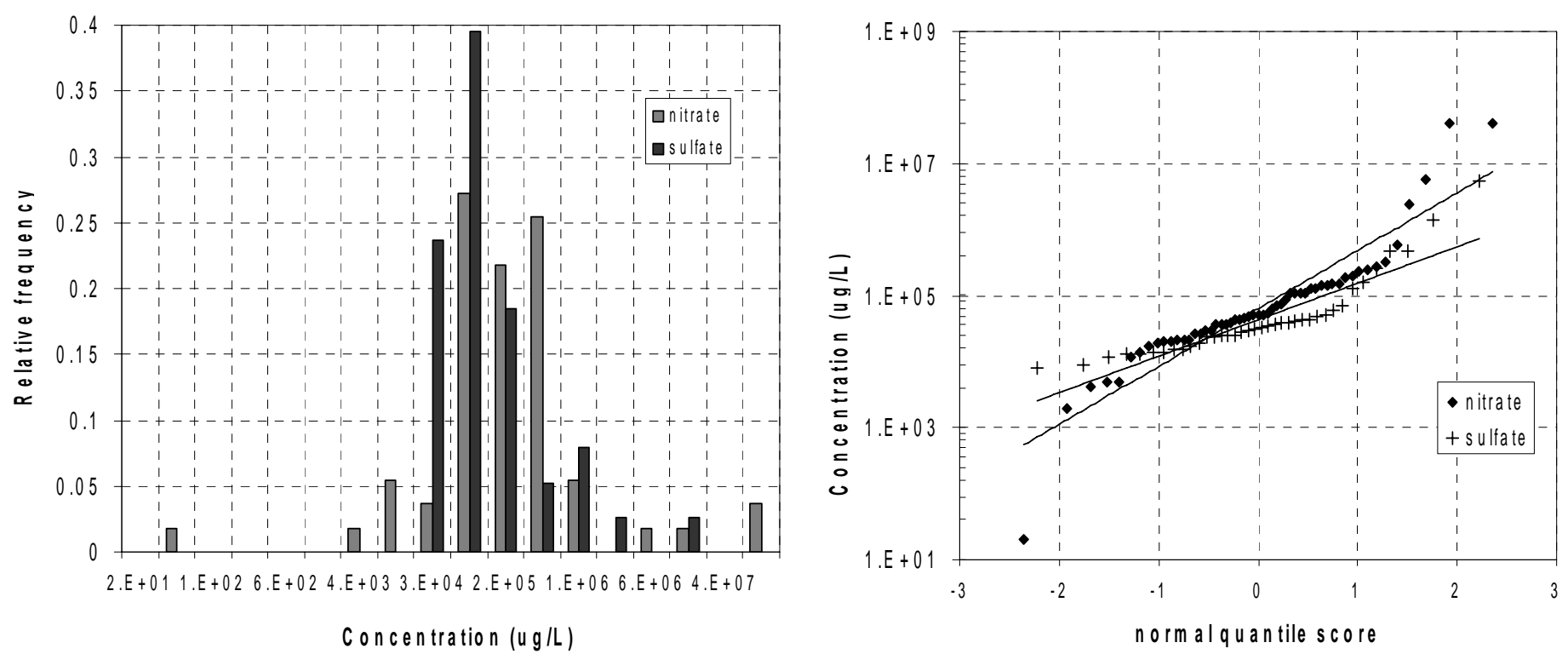

Figure S8. Relative frequency and a normal quantile score vs. maximum concentrations of nitrates and sulfates. Bin values are midpoints in log space. 

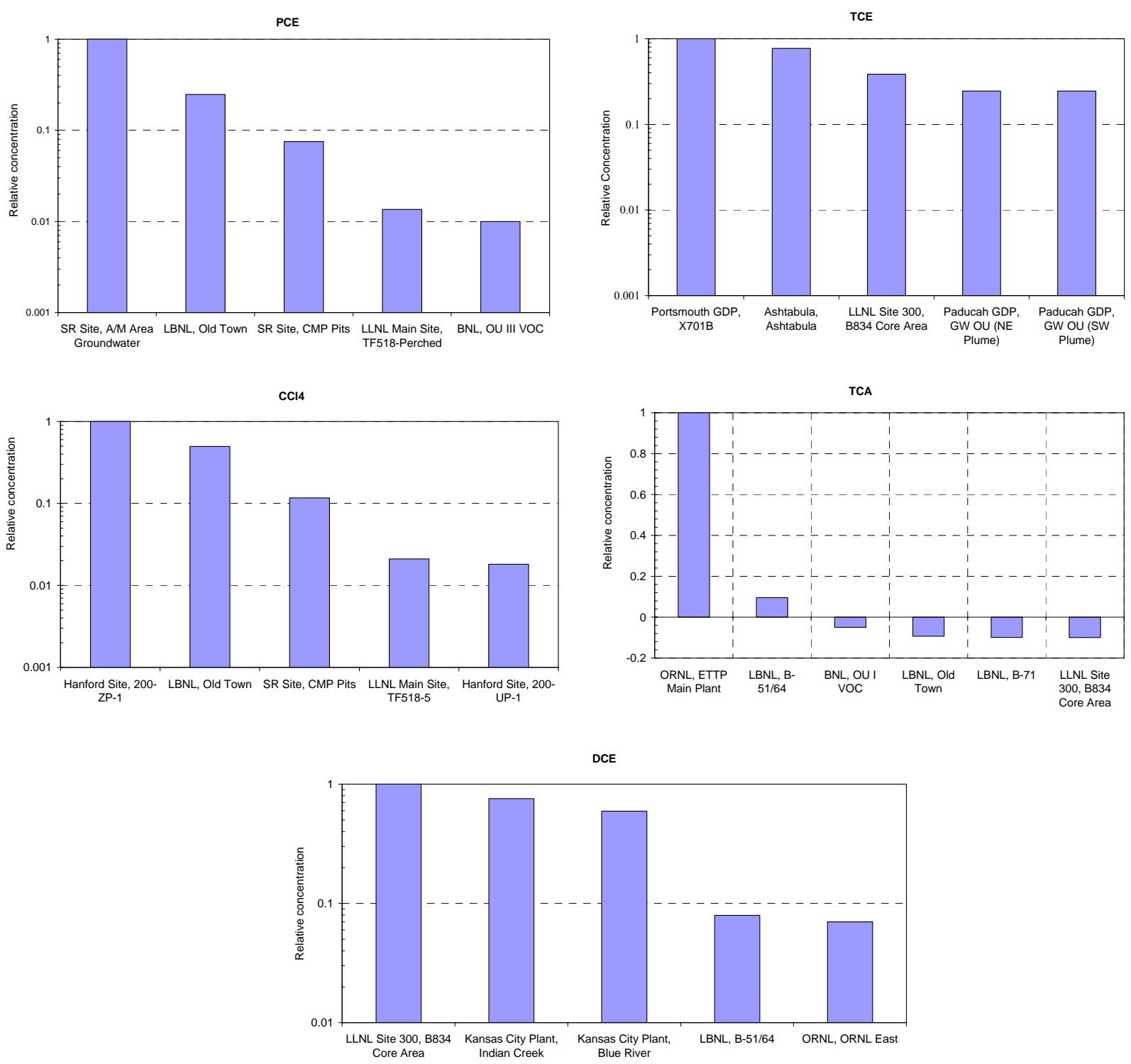

Figure S9. Relative concentration for chlorinated hydrocarbons. Five largest estimates for each contaminant are shown. 

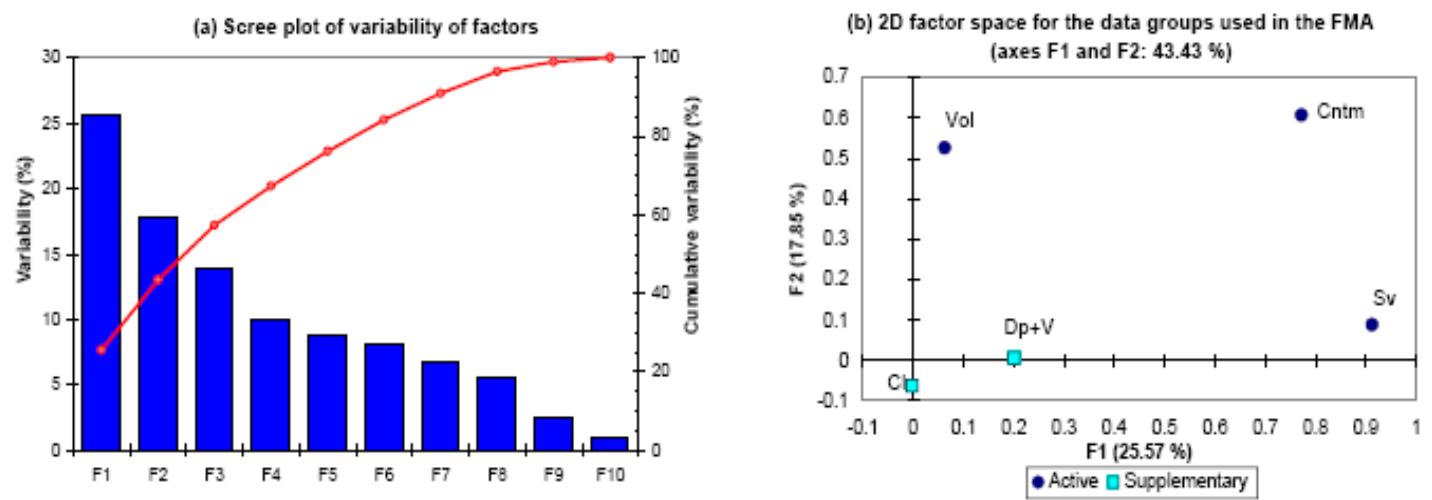

(c) Plot of 2D factor space for the types of contaminant groups and plume depth and velocity - numbers are plume codes (axes F1 and F2: $56.67 \%$ )

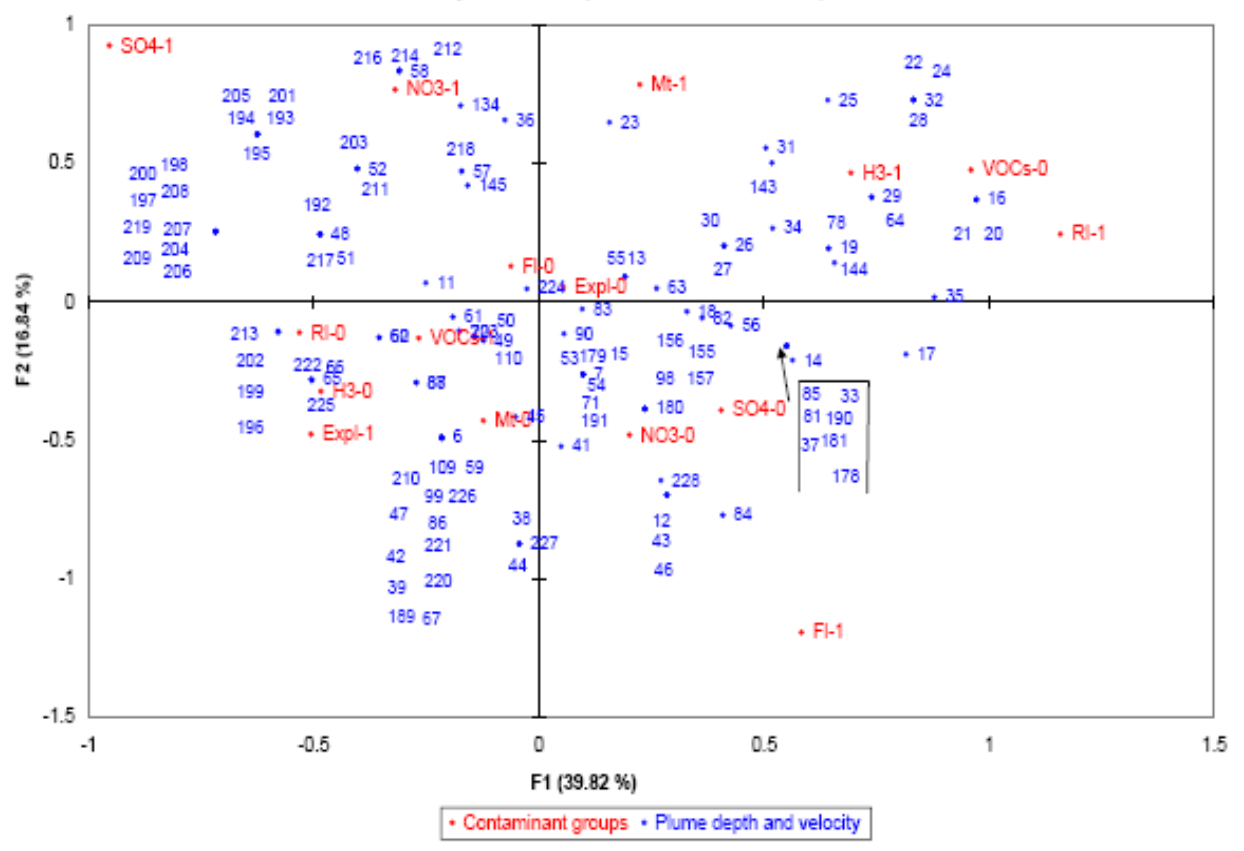

(d) Correlation plot of variables in the factor space

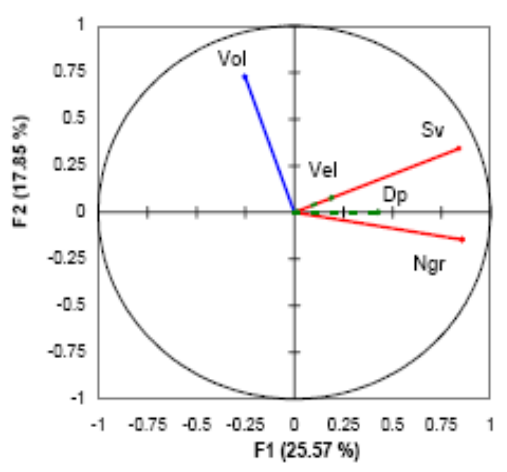

Figure S10. Results of MFA for groundwater plume characteristics (numbers are plume codes - see Table S1) 
(a) Scree plot of variability of factors

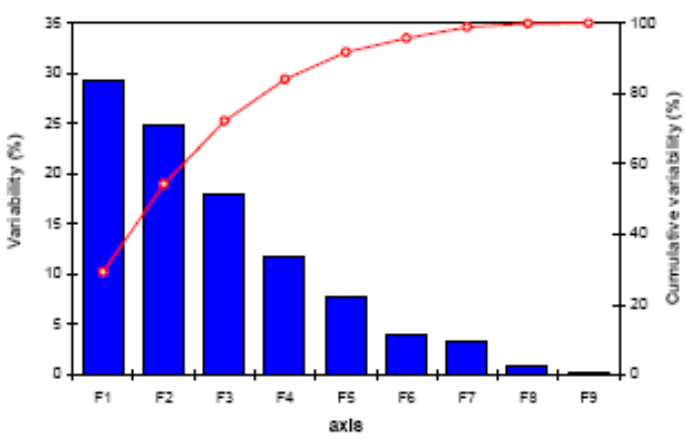

(b) $2 \mathrm{D}$ factor space for the data groups used in the FMA (axes F1 and F2: $54.22 \%$ )

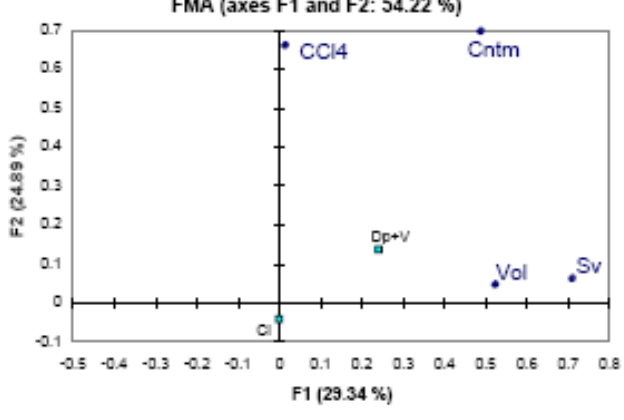

- Active a Supplementary

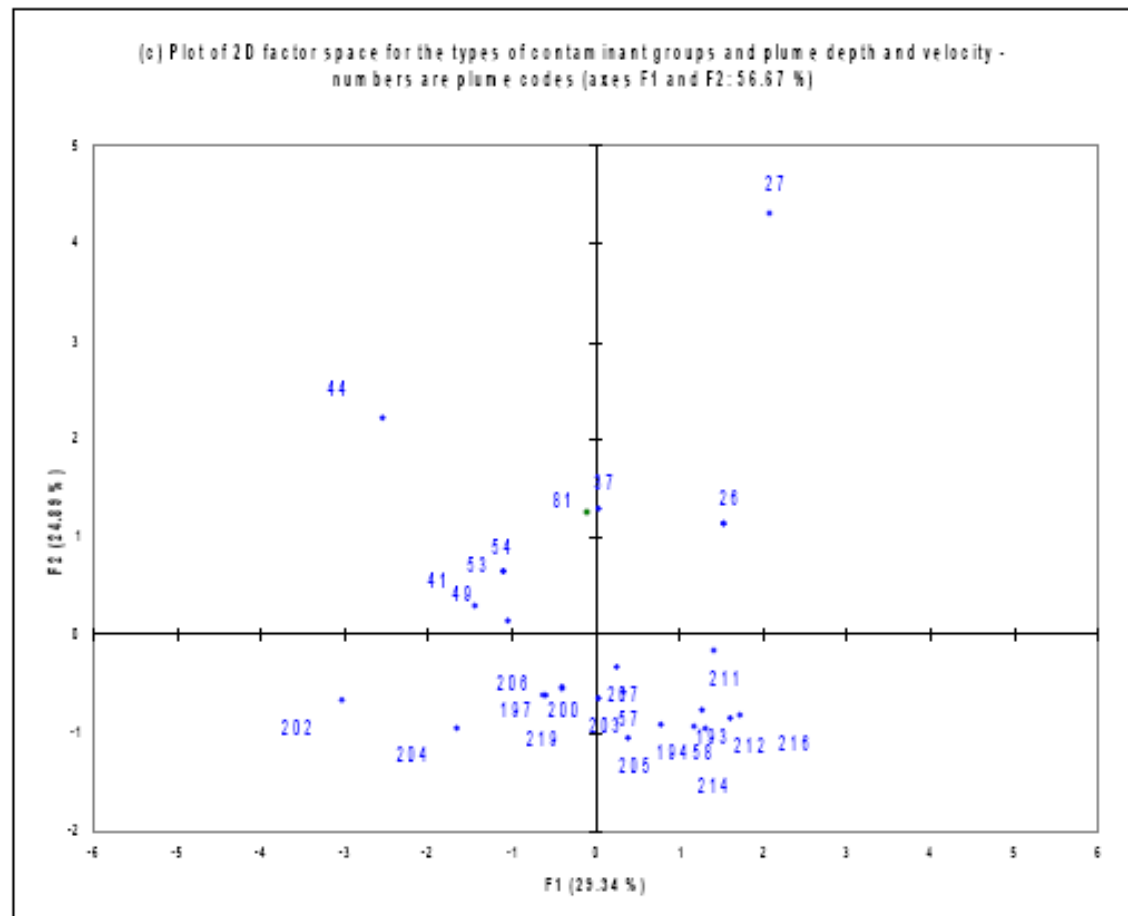

(d) Correlation plot of variables in the factor space axes $\mathrm{F} 1$ and $\mathrm{F} 2: 54.22$ b1

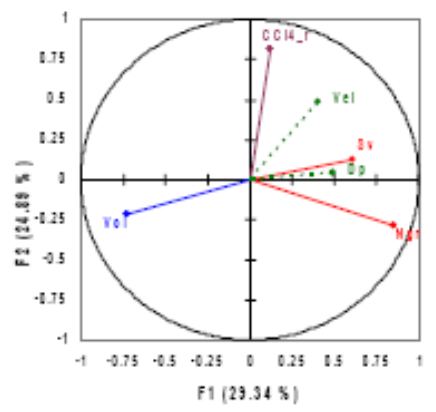

Figure S11. Results of MFA for data groups including CCl4 concentrations 


\section{DISCLAIMER}

This document was prepared as an account of work sponsored by the United States Government. While this document is believed to contain correct information, neither the United States Government nor any agency thereof, nor The Regents of the University of California, nor any of their employees, makes any warranty, express or implied, or assumes any legal responsibility for the accuracy, completeness, or usefulness of any information, apparatus, product, or process disclosed, or represents that its use would not infringe privately owned rights. Reference herein to any specific commercial product, process, or service by its trade name, trademark, manufacturer, or otherwise, does not necessarily constitute or imply its endorsement, recommendation, or favoring by the United States Government or any agency thereof, or The Regents of the University of California. The views and opinions of authors expressed herein do not necessarily state or reflect those of the United States Government or any agency thereof or The Regents of the University of California.

Ernest Orlando Lawrence Berkeley National Laboratory is an equal opportunity employer. 